\title{
Analisis Termodinamika Molekul Magnesium Sulphate $\left(\mathrm{MgSO}_{4}\right)$
}

\author{
Febri Yuliani $^{* 1}$, Rahadian Zainul ${ }^{2}$ \\ ${ }^{1}$ Pendidikan Kimia, FMIPA, Universitas Negeri Padang, Indonesia \\ ${ }^{2}$ Laboratorium Kimia Fisika, FMIPA, Universitas Negeri Padang, Indonesia \\ *Email : febri.yuliani02@gmail.com
}

\begin{abstract}
Abstrak. Magnesium sulfat merupakan salah satu garam anorganik dengan rumus kimia $\mathrm{MgSO}_{4}$. Magnesium sulfat ini termasuk senyawa ionik karena terdapat ikatan antara logam magnesium dengan spesi non logam sulfat. Magnesium sulfat bersifat polar, bentuk anhidratnya sangat higroskopik dan mudah memiliki koordinasi dengan air. Umumnya magnesium sulfat terbentuk dalam formasi hidrat $\mathrm{MgSO}_{4} \cdot x \mathrm{H}_{2} \mathrm{O}$. Penelitian ini bertujuan untuk menganalisis pengaruh sifat termodinamika molekul $\mathrm{MgSO}_{4}$ terhadap interaksi molekuler di dalam senyawa tersebut. Metode yang digunakan ialah pemodelan dengan aplikasi ChemOffice 15.0. Sedangkan untuk data mobilitas ion, konduktivitas, viskositas, kecepatan hanyut dengan menggunakan perhitungan dan data dari hasil review beberapa jurnal penelitian yang berkaitan dengan magnesium sulfat sesuai tahapan yang tertera pada fishbond. Magnesium sulfat memiliki sifat termokimia dalam fasa solid dengan $\Delta H f, \Delta G f, S^{\circ}$, dan $C p$ pada tekanan 1 atm dan suhu $25^{\circ} \mathrm{C}$ yang masing-masing mempunyai nilai $-1284,9 \mathrm{~kJ} / \mathrm{mol},-1170,7 \mathrm{~kJ} / \mathrm{mol}, 91,6 \mathrm{~J} / \mathrm{molK}$ dan 96,48 J/molK. Mobilitas ion $\mathrm{Mg}^{2+}$ dan $\mathrm{SO}_{4}{ }^{2-}$ adalah 5,50.10 $0^{-8} \mathrm{~m}^{2} \mathrm{~s}^{-1} \mathrm{~V}^{-1}$ dan 8,29.10${ }^{8} \mathrm{~m}^{2} \mathrm{~s}^{-1} \mathrm{~V}^{-1}$. Panas reaksi standar $\left(\Delta \mathrm{Hr}^{\circ}\right) \mathrm{MgSO}_{4}$ bernilai negatif maka reaksi bersifat eksotermis.
\end{abstract}

Keyword : Magnesium sulfat, termodinamika, interaksi molekuler

\section{Pendahuluan}

Magnesium sulfat merupakan garam tak berbau yang memiliki rasa asin yang pahit dan umumnya dijumpai sebagai kristal tak berwarna atau padatan kristalin putih. Senyawa ini sangat mudah larut dalam air panas. Magnesium sulfat ialah suatu garam anorganik yang mengandung unsur magnesium, sulfur dan oksigen, dengan rumus $\mathrm{MgSO}_{4}$. Dalam molekul sulfat terdapat ikatan kovalen antara atom belerang (sulfur) dengan atom oksigen. Magnesium sulfat umumnya terbentuk dalam formasi hidrat $\mathrm{MgSO}_{4} \cdot \mathrm{H}_{2} \mathrm{O}$ dan tergolong senyawa ionik $^{(89 ; 90)}$.

Di alam senyawa ini terdapat dalam bentuk mineral sulfat. Magnesium sulfat $\left(\mathrm{MgSO}_{4}\right)$ atau yang sering disebut dengan garam Inggris yang dapat dijumpai dalam bentuk magnesium sulfat heptahidrat $\left(\mathrm{MgSO}_{4} .7 \mathrm{H}_{2} \mathrm{O}\right)$ merupakan salah satu produk industri. $\mathrm{MgSO}_{4} .7 \mathrm{H}_{2} \mathrm{O}$ atau magnesium sulfat heptahidrat sering dinamakan dengan garam Epsom $^{(91-95)}$.

Magnesium sulfat memiliki nilai pH sekitar 6,0 $(5,5-6,5)$ pada keadaan standar dan tekanan uap pada suhu $20^{\circ} \mathrm{C}<0,01 \mathrm{mmHg}{ }^{(96-98)}$. Magnesium sulfat anhidrat (99-103) bersifat sangat higroskopik oleh karenanya senyawa magnesium sulfat biasa didapati dalam bentuk hidrat dengan struktur kristal monoklin. Magnesium sulfat anhidrat memiliki berat molekul 120,366 $\mathrm{g} / \mathrm{mol}$ sedangkan pada magnesium sulfat heptahidrat memiliki berat molekul sebesar 246,47 g/mol. Densitas untuk magnesium sulfat anhidrat dengan 
magnesium sulfat yang mengandung hidrat memiliki data yang berbeda. Densitas magnesium sulfat anhidrat ialah 2,66 gram $/ \mathrm{cm}^{3}$, magnesium sulfat monohidrat sebesar $2,445 \mathrm{gram} / \mathrm{cm}^{3}$, magnesium sulfat heptahidrat $1,68 \mathrm{gram} / \mathrm{cm}^{3}$, magnesium sulfat 11-hidrat ialah $1,512 \mathrm{gram} / \mathrm{cm}^{3}(104-110)$.

Begitu pula untuk nilai titik lebur magnesium sulfat, pada tekanan $1 \mathrm{~atm}$ magnesium sulfat anhidrat memiliki nilai titik lebur $1124{ }^{\circ} \mathrm{C}$, untuk magnesium monohidrat nilai titik leburnya ialah $200{ }^{\circ} \mathrm{C}$, magnesium sulfat heptahidrat nilai titik leburnya ialah $150{ }^{\circ} \mathrm{C}$, dan magnesium undekahidrat ialah $20^{\circ} \mathrm{C}^{(14 ; 56 ; 57 ; 111-113)}$.

Magnesium sulfat ialah garam yang mudah larut dalam air panas. Kelarutan magnesium sulfat anhidrat dalam air bersuhu $0{ }^{\circ} \mathrm{C}$ ialah sebesar $26,9 \mathrm{gr} / 100 \mathrm{ml} \mathrm{H}_{2} \mathrm{O}$. Magnesium sulfat anhidrat juga dapat larut pada air bersuhu $20^{\circ} \mathrm{C}$ sebesar $25,5 \mathrm{gr} / 100 \mathrm{ml}$ $\mathrm{H}_{2} \mathrm{O}$. Sedangkan magnesium sulfat heptahidrat memiliki kelarutan sebesar $71 \mathrm{gr} / 100 \mathrm{ml}$ $\mathrm{H}_{2} \mathrm{O}$ pada suhu $20^{\circ} \mathrm{C}^{(114-118)}$.

Magnesium sulfat memiliki nilai konduktivitas ${ }^{(43 ; 68-71)}$. Besarnya konduktivitas ditentukan oleh konsentrasi elektrolit. Pembawa muatan dapat berupa elektron seperti logam atau dapat juga digunakan ion positif dan ion negatif seperti dalam larutan elektrolit dan leburan garam. Arus listrik terjadi didalam suatu larutan karena adanya ion yang bergerak $^{(119-122)}$.

Termokimia $\mathrm{MgSO}_{4}$ dibagi atas dua bagian, yakni entropi molar standar dan entalpi molar standar ${ }^{(53-55)}$. Termokimia magnesium sulfat dalam fasa solid dengan $\Delta H f, \Delta G f, S^{\circ}$, dan $C p$ pada tekanan $1 \mathrm{~atm}$ dan suhu $25^{\circ} \mathrm{C}$ yang masing-masing mempunyai nilai $-1284,9$ $\mathrm{kJ} / \mathrm{mol},-1170,7 \mathrm{~kJ} / \mathrm{mol}, 91,6 \mathrm{~J} / \mathrm{molK}$ dan $96,48 \mathrm{~J} / \mathrm{molK}$. Panas reaksi standar $\left(\Delta \mathrm{Hr}^{\circ}\right)$ $\mathrm{MgSO}_{4}$ bernilai negatif maka reaksi bersifat eksotermis ${ }^{(123-125)}$.

Magnesium sulfat secara komersial umumnya digunakan dalam dunia farmasi baik penggunaan secara eksternal maupun internal ${ }^{(126-129)}$. Selain itu magnesium sulfat digunakan dalam bahan kosmetik karena secara parsial biasanya dapat digunakan sebagai pencegah kerutan sementara akibat peningkatan kekuatan ionnya ${ }^{(25-27 ; 130 ; 131)}$. Penggunaan lainnya pada bidang pertanian, sintesis elektrolit, dan koagulan bahan ${ }^{(13 ; 14 ; 32 ; 33 ; 93 ; 98 ; 117 ; 132-}$ 139).

Penelitian ini bertujuan untuk menganalisis pengaruh sifat termodinamika molekul $\mathrm{MgSO}_{4}$ sehingga diketahui bagaimana interaksi molekuler di dalam senyawa tersebut dengan menggunakan aplikasi Chem Office 15.0 serta untuk mengetahui sifat fisika dan kimianya begitu juga dengan penggunaannya dalam kehidupan.

\section{Metodologi}

Penelitian kali ini menggunakan metode penggambaran molekul dengan aplikasi ChemOffice 15.0. Untuk analisis lanjut mengenai $\mathrm{MgSO}_{4}$ dilakukan beberapa tahapan sesuai yang tertera pada fishbond dibawah ini.

Penelitian dilakukan dengan tahap, yakni (1) Analisis molekul $\mathrm{MgSO}_{4}$ secara dua dimensi dengan menggunakan ChemDraw 2D, (2) Analisis molekul $\mathrm{MgSO}_{4}$ secara tiga dimensi menggunakan Chem3D.

Pada bagian Chem3D, struktur $\mathrm{MgSO}_{4}$ diubah menjadi bentuk 3 dimensi dan kemudian dianalisis, seperti :

1. Menghitung MM2 dari masing-masing molekul yang terdiri atas MM2 minimization, MM2 dynamics dan MM2 properties. Langkahnya dengan klik pada menu calculation, pilih MM2 minimization kemudian klik minimize energy lalu klik run. Dengan langkah yang sama dilakukan untuk menentukan molecular dynamics dan compute properties.

2. Analisis surface molekul, diantaranya Surface Solvent Accesible dengan tipe solid, wire mesh dan tranculent. Kemudian Surface Connolly Molecular dengan tipe solid, wire mesh dan tranculent.

3. Menghitung nilai MOPAC dari masing-masing molekul yang terdiri dari MOPAC minimization dan MOPAC properties. Caranya dengan pilih MOPAC, kemudian 
pilih MOPAC minization kemudian pilih run. Dengan cara yang sama untuk menentukan MOPAC properties.

4. Analisis jarak antara masing-masing atom tiap-tiap, molekul dengan pilih bagian structure, kemudian pilih measurement.

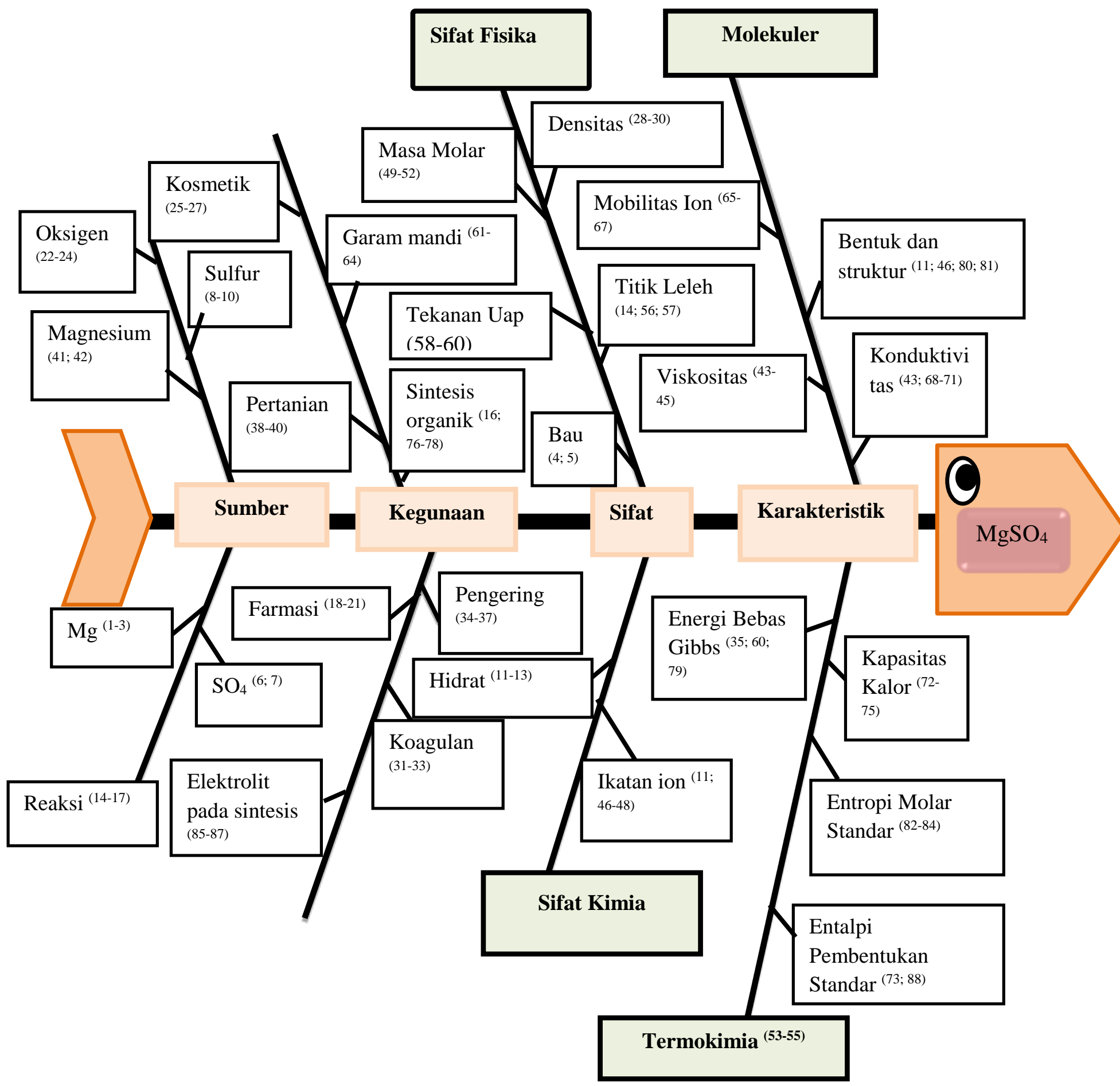

Bagan 1. Fishbone $\mathrm{MgSO}_{4}$ 


\section{Pembahasan}

\subsection{Sifat Magnesium Sulfat $\left(\mathrm{MgSO}_{4}\right)$}

Magnesium sulfat adalah garam anorganik yang mengandung unsur magnesium, sulfur dan oksigen, dengan rumus $\mathrm{MgSO}_{4}$. Magnesium sulfat termasuk senyawa ionik karena terjadi ikatan antara logam magnesium dengan spesi non logam sulfat. Magnesium sulfat bersifat polar, bentuk anhidratnya sangat higroskopik dan mudah memiliki koordinasi dengan air. Dalam molekul sulfat terdapat ikatan kovalen antara atom belerang (sulfur) dengan atom oksigen ${ }^{(89 ; 90)}$

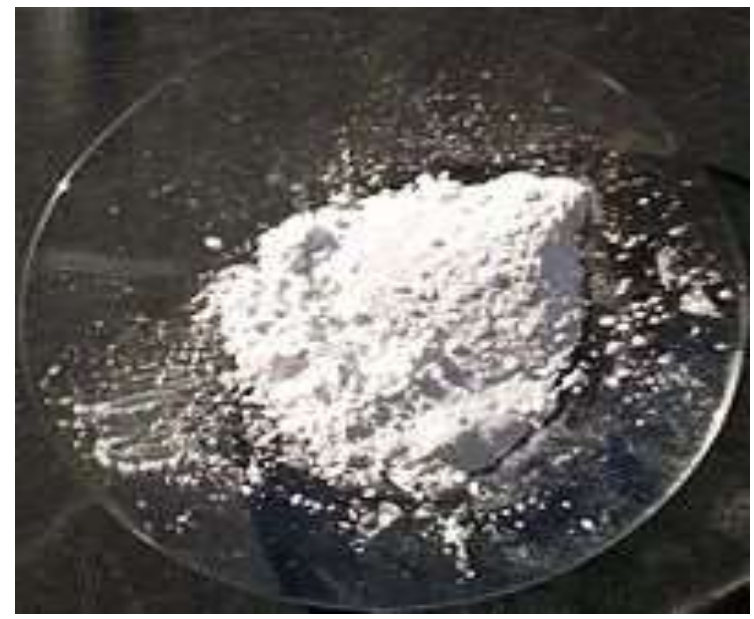

Gambar 1. Magnesium sulfat anhidrat ${ }^{(140)}$

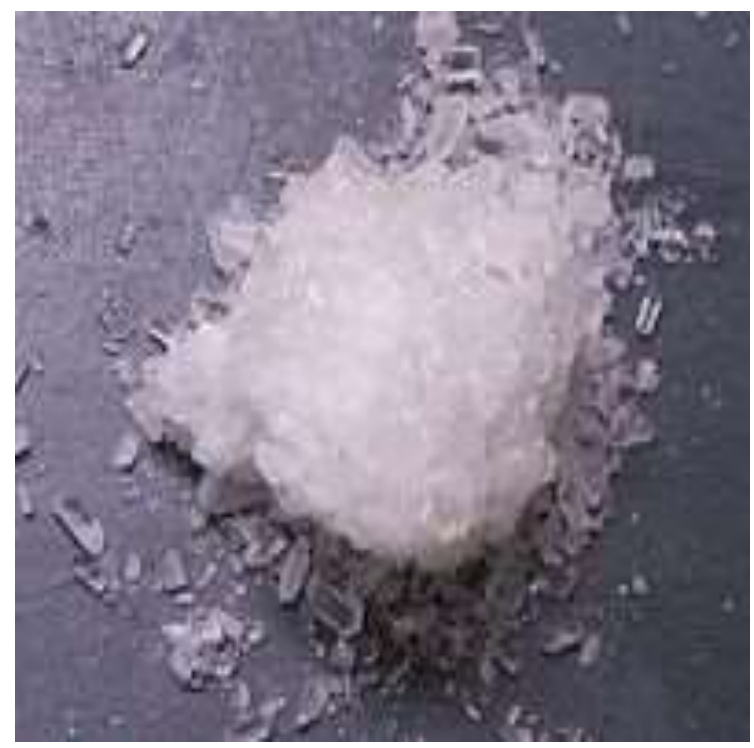

Gambar 2. Magnesium sulfat heptahidrat ${ }^{(141)}$

$\mathrm{MgSO}_{4}$ umumnya dapat dijumpai dalam garam epsomite yakni $\mathrm{MgSO}_{4} .7 \mathrm{H}_{2} \mathrm{O}$. Di alam senyawa ini terdapat dalam bentuk mineral sulfat. Magnesium sulfat $\left(\mathrm{MgSO}_{4}\right)$ atau yang sering disebut dengan garam Inggris yang dapat dijumpai dalam bentuk magnesium sulfat heptahidrat $\left(\mathrm{MgSO}_{4} .7 \mathrm{H}_{2} \mathrm{O}\right)$ merupakan salah satu produk industri ${ }^{(141-146)}$.

Magnesium sulfat ialah padatan tak berbau yang umumnya dijumpai sebagai kristal tak berwarna atau padatan kristalin putih. Senyawa ini sangat mudah larut pada air panas. Sifat dari senyawa $\mathrm{MgSO}_{4}$ ditunjukkan pada tabel berikut: 
Tabel 1. Sifat Fisika dan Kimia Senyawa $\mathrm{MgSO}_{4}(51 ; 107 ; 147-153)$

\begin{tabular}{|c|c|}
\hline Sifat Fisika dan Kimia & Data \\
\hline Penampilan & Kristal padat putih \\
\hline Bau & Tidak berbau \\
\hline Rasa & Pahit, asin, dingin \\
\hline Berat molekul (gr/mol) & 120,366 (anhidrat); 246,47(heptahidrat) \\
\hline Indeks bias $\left(n_{\mathrm{D}}\right)$ & 1,523 (monohidrat); 1,433 (heptahidrat) \\
\hline $\begin{array}{l}\text { Densitas / Massa jenis } \\
\qquad\left(\mathrm{gr} / \mathrm{cm}^{3}\right)\end{array}$ & $\begin{array}{l}\text { 2,66 (anhidrat); 2,445 (monohidrat); } \\
\text { 1,68 (heptahidrat); 1,512 (11-hidrat) }\end{array}$ \\
\hline Titik leleh (1 atm) & $\begin{array}{c}1124{ }^{\circ} \mathrm{C} \text { (Anhidrat); } 200{ }^{\circ} \mathrm{C} \text { (monohidrat); } 150 \\
{ }^{\circ} \mathrm{C} \text { (heptahidrat); } 20{ }^{\circ} \mathrm{C} \text { (undekahidrat); }\end{array}$ \\
\hline Tekanan Uap (mmHg) & $<0,01\left(20^{\circ} \mathrm{C}\right)$ \\
\hline Kelarutan per100 $\mathrm{ml} \mathrm{H}_{2} \mathrm{O}$ & $\begin{array}{c}26,9 \mathrm{gr}\left(0^{\circ} \mathrm{C}\right) ; 25,5 \mathrm{gr} \text { anhidrat }\left(20^{\circ} \mathrm{C}\right) ; 71 \mathrm{gr} \\
\text { heptahidrat }\left(20^{\circ} \mathrm{C}\right)\end{array}$ \\
\hline Nilai pH & Sekitar $6,0(5,5-6,5)$ \\
\hline Struktur kristal & monoklin (bentuk hidrat) \\
\hline
\end{tabular}

\subsection{Bentuk Molekul}

Magnesium sulfat ialah senyawa yang terdiri dari atom $\mathrm{Mg}, \mathrm{S}$ dan O. Magnesium termasuk golongan IIA yang mempunyai 2 elektron di kulit terluarnya dan Sulfur merupan golongan VIA yang mempunyai 6 elektron di kulit terluarnya, serta Oksigen juga dari golongan VIA yang mempunyai 6 elektron di kulit terluarnya. Dalam molekul sulfat terdapat ikatan kovalen antara atom belerang (sulfur) dengan atom oksigen ${ }^{(11 ; 21 ; 98 ; 154 ; 155)}$.

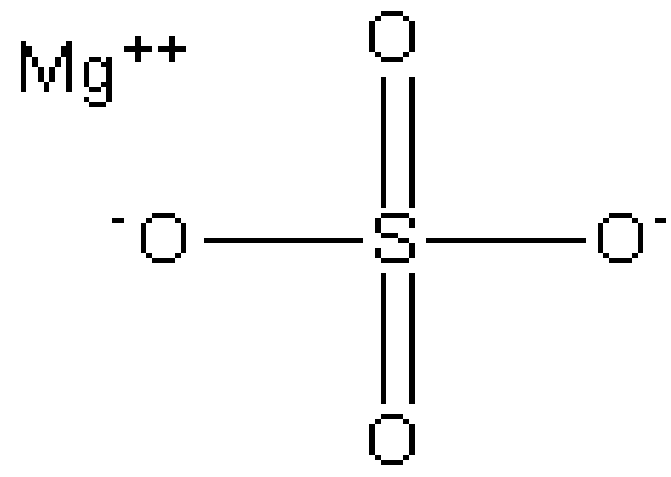

Gambar 3. Molekul $\mathrm{MgSO}_{4}$ dalam 2 dimensi (Chemoffice 2D Version 15, Perkinelmer Informatic. Inc, 2015) 


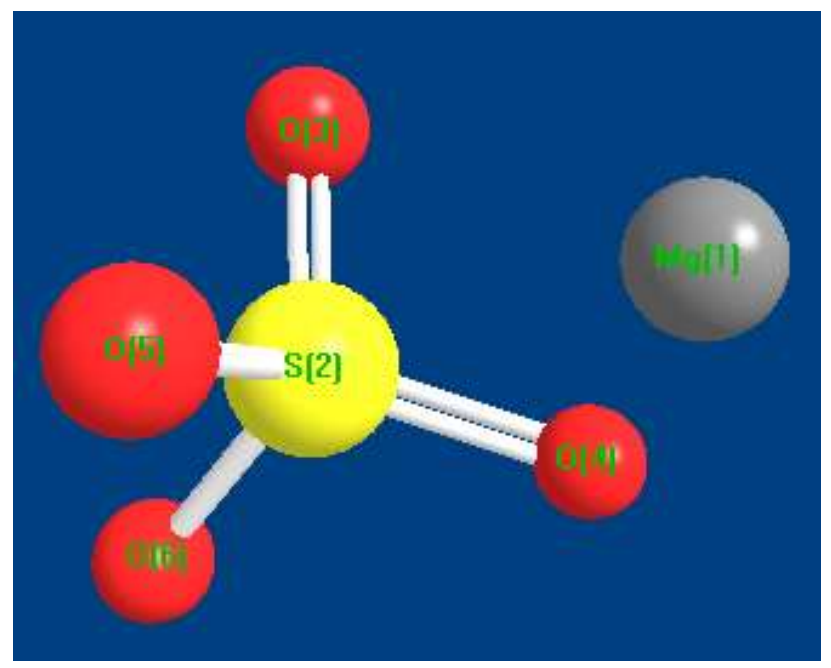

Gambar 4. Molekul $\mathrm{MgSO}_{4}$ dalam 3 dimensi (Chemoffice 2D

Version 15, Perkinelmer Informatic. Inc, 2015)

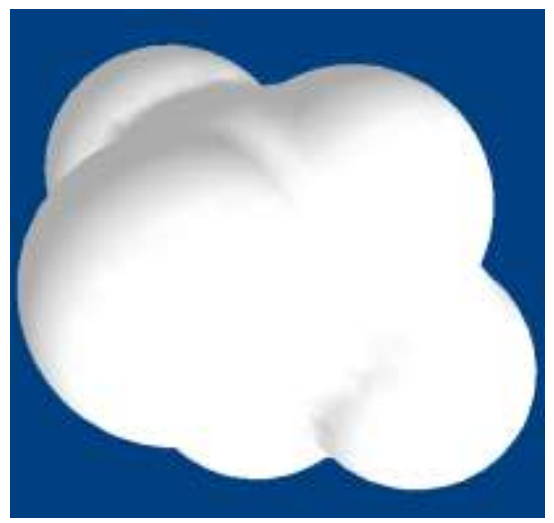

(a)

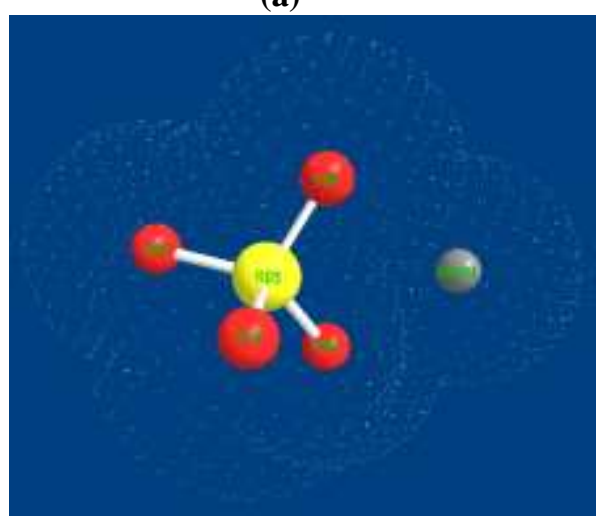

(c)

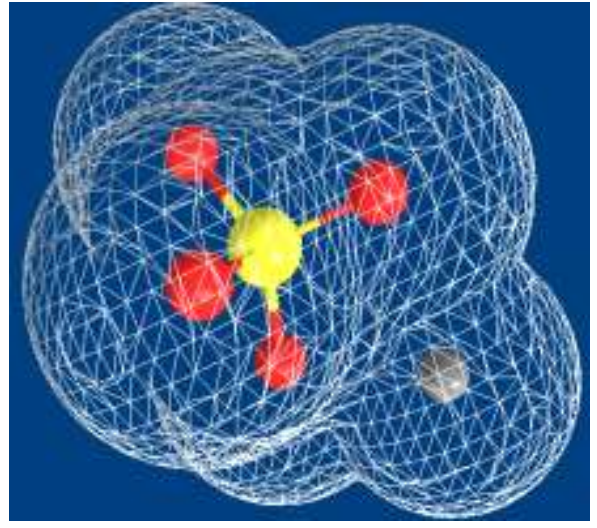

(b)

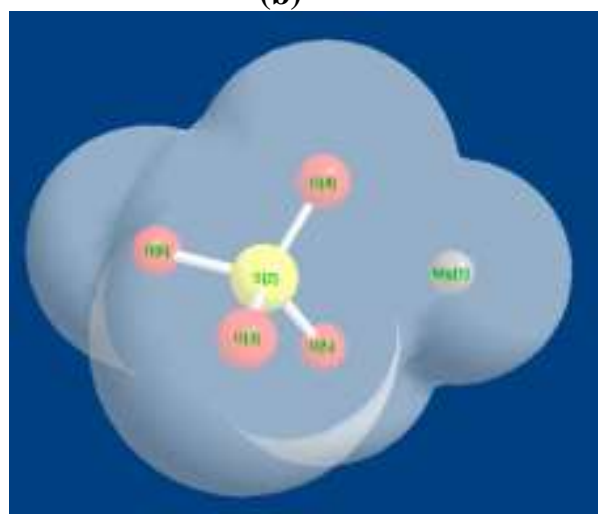

(d) 


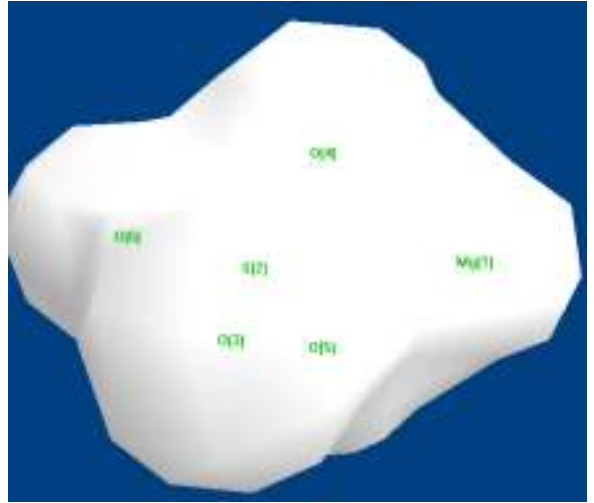

(e)

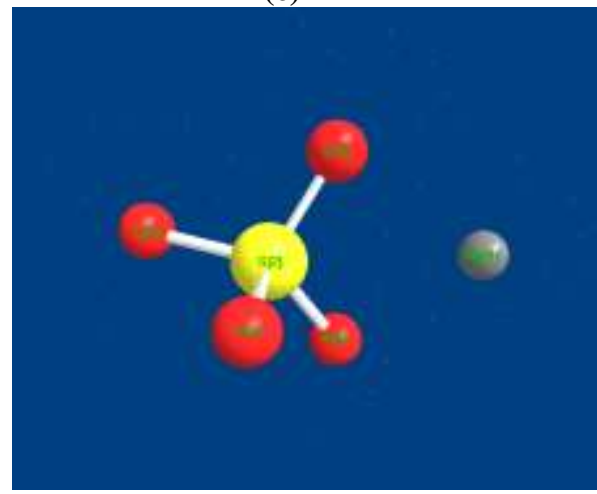

(g)

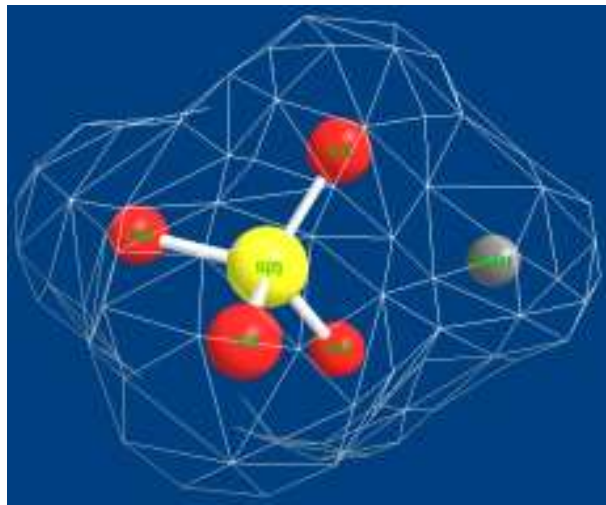

(f)

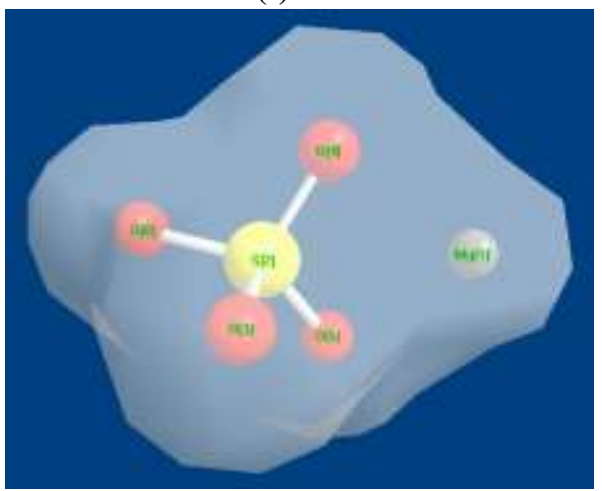

(h)

Gambar 5.Analisis 3D Surface $\mathrm{NH}_{4} \mathrm{OH}$. (a), (b), (c), dan (d) Solvent Accessible Molekul $\mathrm{MgSO}_{4}$ Mode Solid, Wire Mesh, Dots dan Translucent. (e), (f), (g), dan (h) Connolly Molecular $\mathrm{MgSO}_{4}$ Mode Solid, Wire Mesh, Dots dan Translucent. (Chemoffice 3D Version 15, Perkinelmer Informatic. Inc, 2015)

\subsection{Sintesis Magnesium Sulfat ${ }^{(137 ; 156-162)}$}

Macam-macam proses pembuatan magnesium sulfat mempunyai rangkaian proses yang relatif sederhana, teknologi proses yang dipakai dewasa ini memberikan dua alternatif proses, yaitu:

\subsubsection{Proses I (Reaksi Netralisasi)}

Reaksi: $\mathrm{MgO}+\mathrm{H}_{2} \mathrm{SO}_{4} \rightarrow \mathrm{MgSO}_{4}+\mathrm{H}_{2} \mathrm{O}$

Magnesium oksida direaksikan dengan $\mathrm{H}_{2} \mathrm{SO}_{4}$ di dalam reaktor pada kondisi operasi suhu $70^{\circ} \mathrm{C}$ dan tekanan $1 \mathrm{~atm}$, maka terbentuk slurry $\mathrm{MgSO}_{4}$.

Slurry yang terbentuk diteruskan ke dalam filter untuk menghilangkan impuritas sebelum dimasukkan ke dalam evaporator untuk dipekatkan dan di masukkan ke crystallizer untuk pembentukan kristal $\mathrm{MgSO}_{4} .7 \mathrm{H}_{2} \mathrm{O}$.

Berikut sifat dari bahan baku pada reaksi netralisasi ini:

\subsubsection{Magnesium Oksida} $\mathrm{MgO}$.

Magnesium oksida memiliki bentuk bubuk berwarna putih dengan rumus molekul 
Tabel 2. Sifat Fisika dan Kimia Senyawa MgO

\begin{tabular}{cc}
\hline Sifat & Data \\
\hline Berat molekul & $40,304 \mathrm{~kg} / \mathrm{kmol}$ \\
Indeks bias & 1,736 \\
Densitas & $3,65 \mathrm{~g} / \mathrm{cm}^{3}$ \\
Titik leleh $(1 \mathrm{~atm})$ & $300^{\circ} \mathrm{C}$ \\
Titik didih $(1 \mathrm{~atm})$ & $850{ }^{\circ} \mathrm{C}$ \\
Kelarutan per100 $\mathrm{ml} \mathrm{H} \mathrm{H}_{2} \mathrm{O}$ & $0,0086 \mathrm{~g}$ \\
\hline
\end{tabular}

\subsubsection{Asam Sulfat}

Asam sulfat dengan rumus molekul $\mathrm{H}_{2} \mathrm{SO}_{4}$ berbentuk cair dan bersifat korosif terhadap semua jenis logam.

Tabel 3. Sifat Fisika dan Kimia Senyawa $\mathrm{H}_{2} \mathrm{SO}_{4}$

\begin{tabular}{cc}
\hline Sifat & Data \\
\hline Berat molekul & $98,07 \mathrm{~kg} / \mathrm{kmol}$ \\
Densitas & $1826,1 \mathrm{~kg} / \mathrm{m}^{3}$ \\
Titik beku $(1 \mathrm{~atm})$ & $10,5^{\circ} \mathrm{C}$ \\
Titik didih $(1 \mathrm{~atm})$ & 340 \\
\hline
\end{tabular}

\subsubsection{Proses II (Reaksi Penguraian)}

Langbeinite $\left(\mathrm{K}_{2} \mathrm{SO}_{4} \cdot 2 \mathrm{MgSO}_{4}\right)$ diuraikan menjadi $\mathrm{MgSO}_{4} \cdot 6 \mathrm{H}_{2} \mathrm{O}$. Proses ini menggunakan air panas suhu $50-60^{\circ} \mathrm{C}$ selama 6 jam. Larutan yang terbentuk kemudian dikristalkan pada suhu $20-35^{\circ} \mathrm{C}$.

Dari beberapa faktor di atas dapat dilihat bahwa proses yang lebih mudah adalah proses 1, dengan pertimbangan: 1 . Bahan baku yang digunakan lebih mudah dan murah untuk mendapatkannya. 2. Proses yang dijalankan lebih aman dan sederhana sihingga dapat menekan biaya pengadaan alat operasi dan pemeliharaannya lebih mudah.

\subsection{Karakteristik Atom Penyusun dan Ion}

\subsubsection{Magnesium}

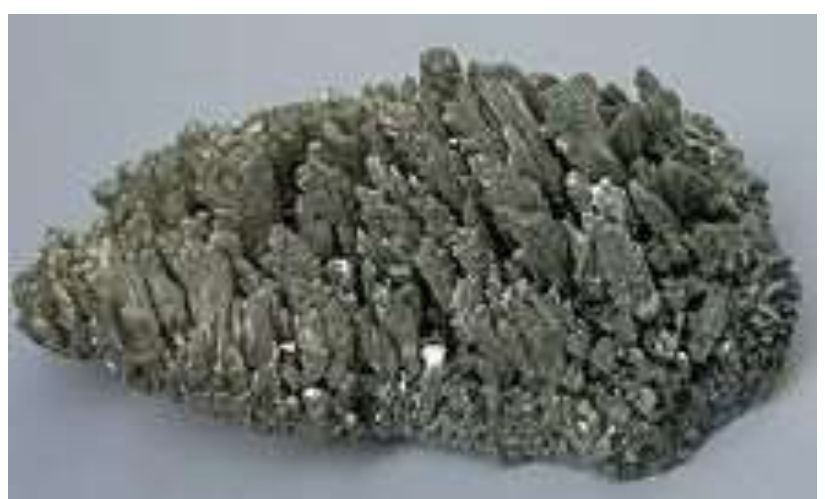

Gambar 6. Logam Magnesium 


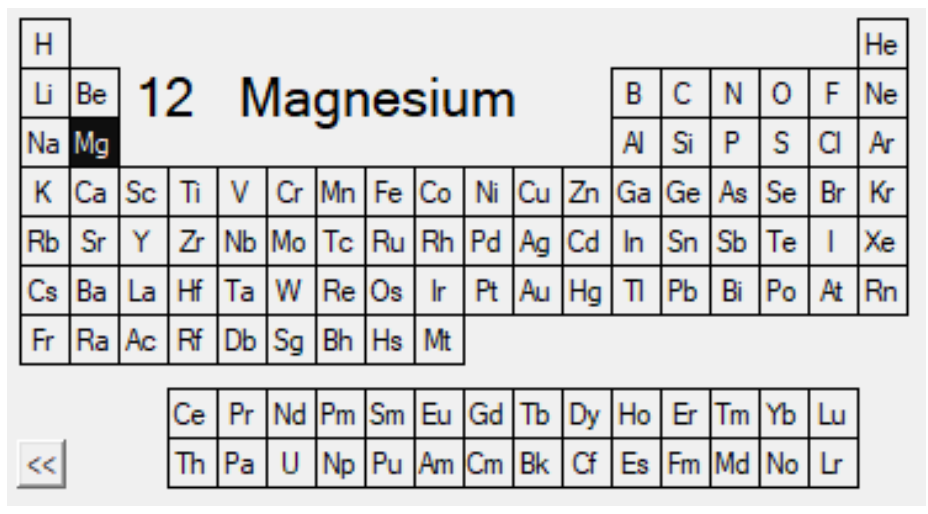

Gambar 7. Magnesium Dalam Tabel Periodik

Magnesium (163-167) ialah salah satu unsur kimia yang memiliki lambang Mg dan nomor atom 12. Bentuknya berupa padatan berwarna abu-abu mengkilap. Magnesiuim memliki tingkat oksidasi +2 dan magnesium terjadi secara alami hanya dalam kombinasi dengan unsur-unsur lain. Dalam bentuk unsur bebasnya logam magnesium sangat reaktif dan terbakar dengan cahaya berwarna putih cemerlang yang khas. Logam nya umumnya diperoleh dari proses elektrolisis garam magnesium yang diperoleh dari air garam. Magnesium bersifat kurang padat dibandingkan dengan aluminium, dan paduannya berharga karena kombinasi antara bobot yang ringan dan kekuatan ${ }^{(168-171)}$.

Magnesium esensial untuk semua sel dan sekitar 300 enzim memerlukan ion magnesium agar berfungsi. Ion magnesium ${ }^{(171-173)}$ berinteraksi dengan senyawa polifosfat seperti DNA, dan RNA. Senyawa magnesium digunakan secara medis sebagai obat dan untuk menstabilkan eksitasi saraf abnormal atau kejang pembuluh darah.

Magnesium memiliki beberapa sifat yaitu :

Tabel 4. Sifat Fisika dan Kimia Unsur Mg ${ }^{(174-179)}$

\begin{tabular}{cc}
\hline Sifat Fisika dan Kimia & Data \\
\hline Penampilan & Padatan berwarna abu-abu mengkilap \\
Bau & Tidak berbau \\
Massa atom $(\mathrm{gr} / \mathrm{mol})$ & 24,305 \\
Jari-jari atom & $160 \mathrm{pm}(1,13 \AA)$ \\
Jari-jari kovalen & $141 \pm 7 \mathrm{pm}$ \\
Jari-jari Van der Waals & $173 \mathrm{pm}$ \\
Jari-jari ion & $0,31 \AA$ \\
Kepadatan $\left(\mathrm{gr} / \mathrm{cc}^{3}\right)$ & 1,738 \\
Titik lebur & $650^{\circ} \mathrm{C}$ \\
Titik didih & $1090^{\circ} \mathrm{C}$ \\
Elektronegativitas & $1,31 \mathrm{pauling}$ \\
Potensial ionisasi & $737,7 \mathrm{kj} / \mathrm{mol}$ \\
Kalor peleburan & $8,48 \mathrm{~kJ} / \mathrm{mol}$ \\
Kalor Penguapan & $128 \mathrm{~kJ} / \mathrm{mol}$ \\
Kapasitas kalor molar & $24,869 \mathrm{~J} /(\mathrm{mol} \cdot \mathrm{K})$ \\
Struktur kristal & $\mathrm{Heksagon}$ \\
\hline
\end{tabular}

\subsubsection{Sulfur (Belerang)}




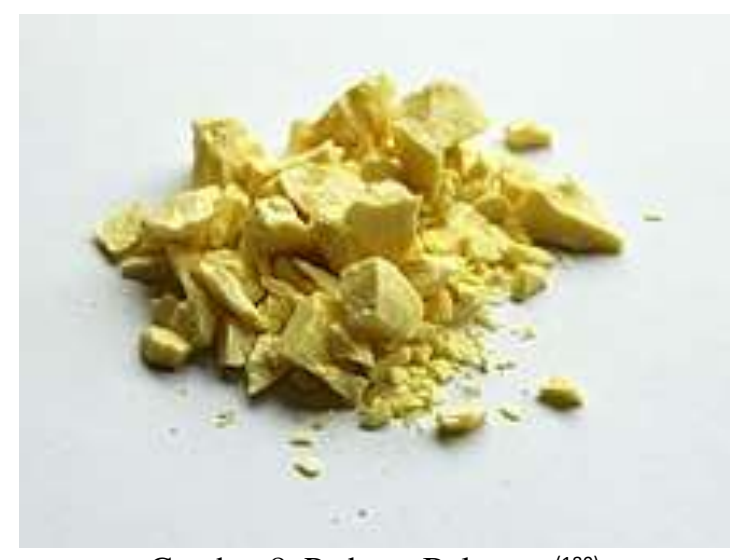

Gambar 8. Padatan Belerang ${ }^{(180)}$

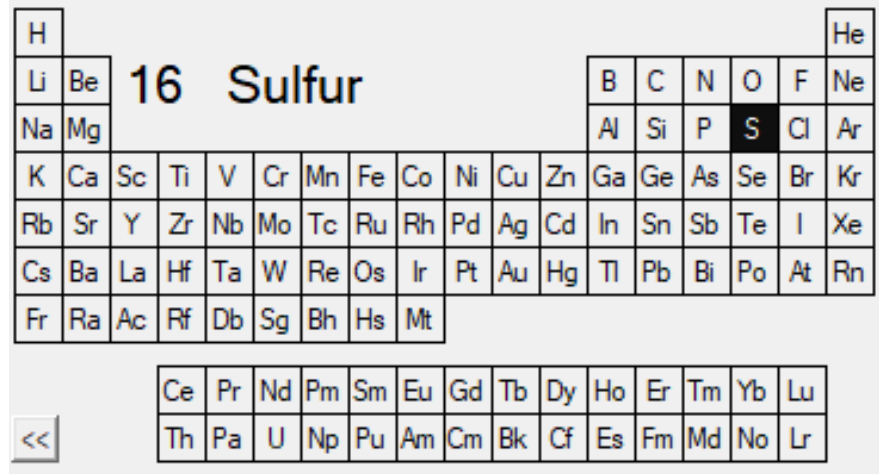

Gambar 9. Sulfur Dalam Tabel Periodik

Belerang atau sulfur merupakan salah satu unsur kimia dalam tabel periodik yang bernomor atom 16 dan memiliki lambang S. Belerang merupakan unsur non logam yang tidak memiliki rasa. Belerang dalam bentuk aslinya berbentuk padatan kristalin kuning. Di alam bebas, belerang ditemukan sebagai unsur murni maupun sebagai mineral-mineral sulfida dan sulfat. Belerang adalah unsur yang ditemukan dalam dua buah asam amino. Contoh penggunaan belerang umumnya adalah dalam pupuk, bubuk mesiu, korek api, insektisida, dan fungisida ${ }^{(22 ; 76 ; 181-186)}$.

Sulfur memiliki beberapa sifat yaitu :

Tabel 5. Sifat Fisika dan Kimia Unsur S ${ }^{22 ; 24 ; 181 ; 186-190)}$

\begin{tabular}{cc}
\hline Sifat Fisika dan Kimia & Data \\
\hline Penampilan & padatan kristalin kuning \\
Rasa & Tidak berasa \\
Massa atom $(\mathrm{gr} / \mathrm{mol})$ & 32,065 \\
Jari-jari atom & $102 \mathrm{pm}$ \\
Jari-jari kovalen & $105 \pm 5 \mathrm{pm}$ \\
Jari-jari Van der Waals & $180 \mathrm{pm}$ \\
Jari-jari Ion & $0,29 \AA(-6)$ \\
& $1,84 \AA(+2)$ \\
Kepadatan $\left(\mathrm{gr} / \mathrm{cc}^{3}\right)$ & 1,96 \\
Titik lebur & $115.21^{\circ} \mathrm{C}$ \\
Titik didih & $444.6^{\circ} \mathrm{C}$ \\
\hline
\end{tabular}




\begin{tabular}{cc}
\hline Elektronegativitas & $2,58 \mathrm{pauling}$ \\
Potensial ionisasi & $999,6 \mathrm{kj} / \mathrm{mol}$ \\
Kalor peleburan & $($ mono) $1.727 \mathrm{~kJ} / \mathrm{mol}$ \\
Kalor Penguapan & (mono) $45 \mathrm{~kJ} / \mathrm{mol}$ \\
Kapasitas kalor molar & $22.75 \mathrm{~J} /(\mathrm{mol} \cdot \mathrm{K})$ \\
Struktur kristal & ortorombus \\
\hline
\end{tabular}

\subsubsection{Oksigen}

\begin{tabular}{|c|c|c|c|c|c|c|c|c|c|c|c|c|c|c|c|c|c|c|}
\hline $\mathrm{H}$ & & & & & & & & & & & & & & & & & & $\mathrm{He}$ \\
\hline نا & $\mathrm{Be}$ & 8 & & & $V$ & $\mathrm{~V}$ & 16 & & & & & & B & C & N & 0 & $F$ & $\mathrm{Ne}$ \\
\hline $\mathrm{Na}$ & $\mathrm{Mg}$ & & & & & & & & & & & & Al & $\mathrm{Si}$ & $P$ & $S$ & $\mathrm{Cl}$ & $\mathrm{Ar}$ \\
\hline $\mathrm{K}$ & $\mathrm{Ca}$ & $\mathrm{Sc}$ & $\mathrm{Ti}$ & V & $\mathrm{Cr}$ & M & & e & Co & $\mathrm{Ni}$ & $\mathrm{Cu}$ & $\mathrm{Zn}$ & Ga & $\mathrm{Ge}$ & As & $\mathrm{Se}$ & $\mathrm{Br}$ & $\mathrm{Kr}$ \\
\hline $\mathrm{Rb}$ & $\mathrm{Sr}$ & $Y$ & Zr & $\mathrm{Nb}$ & Mc & $\mathrm{T}$ & & u & Rh & $\mathrm{Pd}$ & $\mathrm{Ag}$ & $\mathrm{Cd}$ & In & Sn & $\mathrm{Sb}$ & $\mathrm{Te}$ & I & $X_{e}$ \\
\hline Cs & $\mathrm{Ba}$ & La & $\mathrm{Hf}$ & Ta & W & $\mathrm{R}$ & & s & Ir & $\mathrm{Pt}$ & Aus & $\mathrm{Hg}$ & T & $\mathrm{Pb}$ & $\mathrm{Bi}$ & $\mathrm{Po}$ & At & Rn \\
\hline $\mathrm{Fr}$ & $\mathrm{Ra}$ & $A C$ & Rf & $\mathrm{Db}$ & $\mathrm{Sg}$ & $\mid \mathrm{B}$ & & is & Mt & & & & & & & & & \\
\hline & & & $\mathrm{Ce}$ & $\mathrm{Pr}$ & $\mathrm{Nc}$ & & & & Eu & $\mathrm{Gd}$ & $\mathrm{Tb}$ & Dy & $\mathrm{Ho}$ & Er & $\mathrm{Tm}$ & $\mathrm{Yb}$ & $\underline{L u}$ & \\
\hline$\ll$ & & & Th & $\mathrm{Pa}$ & U & $\mathrm{N}$ & & & $\mathrm{Am}$ & $\mathrm{Cm}$ & Bk & Cf & Es & $\mathrm{Fm}$ & Md & No & Lr & \\
\hline
\end{tabular}

Gambar 10. Oksigen Dalam Tabel Periodik

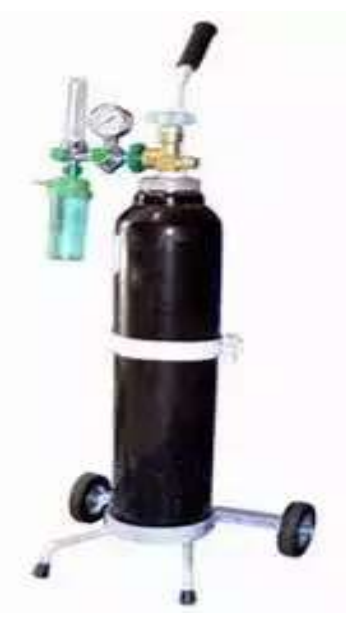

Gambar 11. Gas Oksigen Dalam Tabung (191)

Oksigen ialah salah satu unsur kimia dalam sistem tabel periodik yang bernomor atom 8 dan berlambang O. Oksigen mudah bereaksi dengan hampir semua unsur lainnya (terutama menjadi oksida). Pada keadaan standar, dua atom unsur oksigen berikatan menjadi senyawa dioksigen dengan rumus $\mathrm{O}_{2}$ yang tidak berwarna, tidak berasa, dan tidak berbau $^{(192 ; 193)}$.

Umumnya kelompok molekul dalam makhluk hidup mengandung oksigen. Oksigen dalam bentuk $\mathrm{O}_{2}$ dihasilkan dari air. Gas oksigen digunakan pada proses respirasi oleh hampir semua makhluk hidup ${ }^{(194-196)}$.

Oksigen juga memiliki alotrop lainnya, yakni ozon $\left(\mathrm{O}_{3}\right)$. Lapisan ozon pada atomsfer membantu melindungi permukaan bumi dari radiasi ultraviolet ${ }^{(197-199)}$.

Sulfur memiliki beberapa sifat yaitu : 
Tabel 6. Sifat Fisika dan Kimia Unsur O ${ }^{(15 ; 181 ; 200-203)}$

\begin{tabular}{cc}
\hline Sifat Fisika dan Kimia & Data \\
\hline Penampilan & gas \\
bau & Tidak berbau \\
Massa atom $(\mathrm{gr} / \mathrm{mol})$ & 15,9994 \\
Jari-jari atom & $74 \mathrm{pm}$ \\
Jari-jari kovalen & $66 \pm 2 \mathrm{pm}$ \\
Jari-jari Van der Waals & $152 \mathrm{pm}$ \\
Jari-jari ion & $1,40 \AA \AA^{\AA}(-2)$ \\
Kepadatan $($ gr/cc) & 1,15 \\
Titik lebur & $-218.35^{\circ} \mathrm{C}$ \\
Titik didih & $-182.95^{\circ} \mathrm{C}$ \\
Elektronegativitas & $3,44 \mathrm{pauling}$ \\
Potensial ionisasi & $1313,9 \mathrm{kj} / \mathrm{mol}$ \\
Kalor peleburan & $\left(\mathrm{O}_{2}\right) 0.444 \mathrm{~kJ} / \mathrm{mol}$ \\
Kalor Penguapan & $\left(\mathrm{O}_{2}\right) 6.82 \mathrm{~kJ} / \mathrm{mol}$ \\
Kapasitas kalor molar & $\left(\mathrm{O}_{2}\right) 29.378 \mathrm{~J} /(\mathrm{mol} \cdot \mathrm{K})$ \\
Struktur kristal & $\mathrm{kubus}$ \\
\hline
\end{tabular}

\subsubsection{Sulfat}

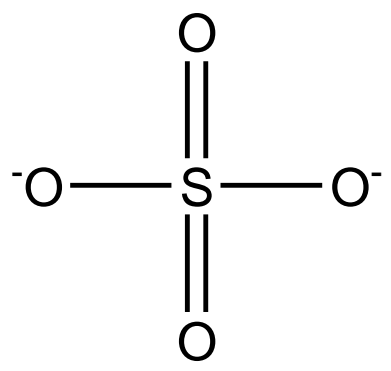

Gambar 12. Anion Sulfat (Chemoffice 2D Version 15, Perkinelmer Informatic. Inc, 2015)

Ion sulfat merupakan anion poliatomik dengan rumus empiris $\mathrm{SO}_{4}{ }^{2-}$. Garam sulfat memiliki beragam aplikasi. Misalnya, magnesium sulfat (atau garam Epsom) digunakan dalam terapi mandi. Beberapa mikroorganisme yang hidup di dekat ventilasi termal laut dalam memanfaatkan sulfat sebagai akseptor elektron ${ }^{(204-208)}$.

Ion sulfat $\left(\mathrm{SO}_{4}{ }^{2-}\right)$ memiliki massa molekul 96,06 dalton. Setiap anion terdiri dari satu atom pusat sulfur yang dikelilingi oleh empat atom oksigen dalam susunan tetrahedral. Senyawa sulfat timbul ketika kation bergabung dengan anion $\mathrm{SO}_{4}{ }^{2-}$. Seringkali kombinasi senyawa sulfat menghasilkan senyawa ionik, meskipun sulfat dapat terlibat dalam ikatan kovalen dengan sebagian besar unsur. Banyak garam sulfat sangat larut dalam air. Pengecualian termasuk kalsium sulfat, strontium sulfat, dan barium sulfat, yang sulit larut ${ }^{(65 ; 209-211)}$.

\subsection{Karakteristik Ikatan Atom-atom pada Senyawa $\mathrm{MgSO}_{4}$}

\begin{tabular}{cccccccc}
\hline \multirow{2}{*}{ Atom } & $\begin{array}{c}\text { Bond } \\
\text { Atom }\end{array}$ & $\begin{array}{c}\text { Bond } \\
\text { Lenght }\end{array}$ & $\begin{array}{c}\text { Angle } \\
\text { Atom }\end{array}$ & $\begin{array}{c}\text { First } \\
\text { Angel }\end{array}$ & $\begin{array}{c}\text { Third } \\
\text { Atom }\end{array}$ & $\begin{array}{c}\text { Second } \\
\text { Atom }\end{array}$ & $\begin{array}{c}\text { Angle } \\
\text { Type }\end{array}$ \\
\hline $\mathrm{S}[2]$ & - & - & - & - & - & - & -
\end{tabular}




\begin{tabular}{cccccccc}
$\mathrm{O}[3]$ & $\mathrm{S}[2]$ & 1.428 & - & - & - & - & - \\
$\mathrm{O}[4]$ & $\mathrm{S}[2]$ & 1.428 & $\mathrm{O}[3]$ & 109.500 & - & - & - \\
$\mathrm{O}[5]$ & $\mathrm{S}[2]$ & 1.660 & $\mathrm{O}[3]$ & 109.500 & $\mathrm{O}[4]$ & 109.500 & Pro S \\
$\mathrm{O}[6]$ & $\mathrm{S}[2]$ & 1.660 & $\mathrm{O}[3]$ & 109.500 & $\mathrm{O}[4]$ & 109.500 & Pro-R \\
$\mathrm{Mg}[1]$ & $\mathrm{O}[6]$ & 4.000 & $\mathrm{~S}[2]$ & 19.107 & $\mathrm{O}[3]$ & -180.000 & Dihedral \\
\hline \multicolumn{7}{c}{ Tabel 7.}
\end{tabular}

Tabel 7. Karakteristik Ikatan Atom-atom pada Senyawa $\mathrm{MgSO}_{4}$

\subsection{Optimasi MM2 Minimization Magnesium Sulfat}

Proses pengolahan data MM2 dengan Chemoffice menunjukkan energi total molekul pada suhu target $300 \mathrm{~K}$ adalah $-260.8281 \mathrm{kcal} / \mathrm{mol}$.

Hasil komputasinya sebagai berikut ;

Iteration 47 Steric Energy -260.262 RMS Gradient 1.786 RMS Move 0.0034

Iteration 48 Steric Energy -260.281 RMS Gradient 2.228 RMS Move 0.0010

Iteration 49 Steric Energy -260.323 RMS Gradient 2.173 RMS Move 0.0027

Iteration 50 Steric Energy -260.339 RMS Gradient 1.729 RMS Move 0.0014

$\begin{array}{lc}\text { Stretch: } & 0.5880 \\ \text { Bend: } & 148.6520 \\ \text { Stretch-Bend: } & -0.8822 \\ \text { Torsion: } & 28.8011 \\ \text { Non-1,4 VDW: } & 80.1119 \\ \text { 1,4 VDW: } & -0.4174 \\ \text { Charge/Charge: } & -568.4317 \\ \text { Charge/Dipole: } & 50.7502 \\ \text { Total Energy: } & -260.8281 \mathrm{kcal} / \mathrm{mol}\end{array}$

Note: Due to high VDW interactions, some terms were not computed.

Calculation ended

\subsection{Optimasi MM2 Dinamics Magnesium Sulfat}

MM2 Calculation completed successfully

-MM2 Dynamics

Warning: Some parameters are guessed (Quality $=1$ ).

Iteration Time Total Energy Potential Energy Temperature

$$
\begin{array}{ccccccc}
1 & 0.002 & -260.828 \pm & 0.000 & -260.828 \pm 0.000 & 0.00 \pm 0.00 \\
2 & 0.004 & -260.758 \pm & 0.000 & -260.782 \pm 0.000 & 0.80 \pm 0.00 \\
3 & 0.006 & -260.656 \pm & 0.000 & -260.680 \pm 0.000 & 0.81 \pm 0.00 \\
4 & 0.008 & -260.464 \pm & 0.000 & -260.527 \pm 0.000 & 2.13 \pm 0.00 \\
5 & 0.010 & -260.114 \pm & 0.000 & -260.199 \pm 0.000 & 2.87 \pm 0.00 \\
6 & 0.012 & -259.793 \pm & 0.000 & -259.969 \pm 0.000 & 5.91 \pm 0.00 \\
7 & 0.014 & -259.046 \pm & 0.000 & -259.318 \pm 0.000 & 9.11 \pm 0.00 \\
8 & 0.016 & -258.901 \pm 0.000 & -259.277 \pm 0.000 & 12.63 \pm 0.00 \\
9 & 0.018 & -258.126 \pm & 0.000 & -258.636 \pm 0.000 & 17.11 \pm 0.00 \\
10 & 0.020 & -258.524 \pm 0.000 & -259.123 \pm 0.000 & 20.12 \pm 0.00
\end{array}
$$

Step sampai 50

Calculation ended

\subsection{Optimasi MM2 Properties Magnesium Sulfat}


Warning: Some parameters are guessed (Quality $=1)$.

$\begin{array}{lc}\text { Stretch: } & 1.0142 \\ \text { Bend: } & 152.9931 \\ \text { Stretch-Bend: } & -1.1163 \\ \text { Torsion: } & 29.0142 \\ \text { Non-1,4 VDW: } & 80.6804 \\ \text { 1,4 VDW: } & -0.2441 \\ \text { Charge/Charge: } & -569.0403 \\ \text { Charge/Dipole: } & 50.7909 \\ \text { Total Energy: } & -255.9079 \mathrm{kcal} / \mathrm{mol}\end{array}$

Note: Due to high VDW interactions, some terms were not computed.

cubic stretch: $\quad-2.0000$

quartic stretch: 2.3330

p->dielec: $\quad 1.5000$

p->dieled: $\quad 1.5000$

$\begin{array}{lccll}\text { Bond Atoms } & \text { Length } & \mathrm{R}(0) & \mathrm{K}(\mathrm{S}) & \text { Energy } \\ \mathrm{S}(2)-\mathrm{O}(3) & 1.439 & 1.4500 & 8.4120 & 0.0738 \\ \mathrm{~S}(2)-\mathrm{O}(4) & 1.446 & 1.4500 & 8.4120 & 0.0109 \\ \mathrm{~S}(2)-\mathrm{O}(5) & 1.678 & 1.6600 & 15.0000 & 0.3452 \\ \mathrm{~S}(2)-\mathrm{O}(6) & 1.682 & 1.6600 & 15.0000 & 0.4824 \\ \text { O(3)-Lp(7) } & 0.617 & 0.6000 & 4.6000 & 0.0966 \\ \text { O(3)-Lp(8) } & 0.599 & 0.6000 & 4.6000 & 0.0004 \\ \text { O(4)-Lp(9) } & 0.596 & 0.6000 & 4.6000 & 0.0050 \\ \text { O(4)-Lp(10) } & 0.600 & 0.6000 & 4.6000 & 0.0000\end{array}$

$\begin{array}{lllllll}\text { Angle Atoms } & \text { Theta } & \text { Tzero } & \text { KB } & \text { EB } & \text { KSB } & \text { ESB } \\ \text { O(3)-S(2)-O(4) } & 129.246 & 116.6000 & 0.9000 & 3.1597 & 0.25 & -0.1202 \\ \text { O(3)-S(2)-O(5) } & 111.652 & 109.5000 & 0.5000 & 0.0507 & 0.25 & 0.0098 \\ \text { O(3)-S(2)-O(6) } & 112.363 & 109.5000 & 0.5000 & 0.0898 & 0.25 & 0.0192 \\ \text { O(4)-S(2)-O(5) } & 109.655 & 109.5000 & 0.5000 & 0.0003 & 0.25 & 0.0014 \\ \text { O(4)-S(2)-O(6) } & 109.298 & 109.5000 & 0.5000 & 0.0004 & 0.25 & -0.0022 \\ \text { O(5)-S(2)-O(6) } & 68.523 & 109.5000 & 0.5000 & 22.0287 & 0.25 & -1.0242 \\ \text { S(2)-O(3)-Lp(7) } & 142.330 & 180.0000 & 0.5000 & 17.7397 & & \\ \text { S(2)-O(3)-Lp(8) } & 143.304 & 180.0000 & 0.5000 & 16.6281 & & \\ \text { Lp(7)-O(3)-Lp(8 } & 74.366 & 131.0000 & 0.2400 & 29.0174 & & \\ \text { S(2)-O(4)-Lp(9) } & 136.036 & 180.0000 & 0.5000 & 26.7164 & & \\ \text { S(2)-O(4)-Lp(10 } & 137.576 & 180.0000 & 0.5000 & 24.1914 & & \\ \text { Lp(9)-O(4)-Lp(1 } & 86.387 & 131.0000 & 0.2400 & 13.3705 & & \end{array}$

$\begin{array}{lcccccc}\text { Dihedral Atoms } & \text { Omega } & \text { V1 } & \text { V2 } & \text { V3 } & \text { Et } \\ \text { O(4)-S(2)-O(3)-Lp(7) } & -179.578 & 0.0000 & 10.0000 & 0.0000 & 0.0005 \\ \text { O(4)-S(2)-O(3)-Lp(8) } & 0.088 & 0.0000 & 10.0000 & 0.0000 & 0.0000 \\ \text { O(5)-S(2)-O(3)-Lp(7) } & -37.245 & 0.0000 & 10.0000 & 0.0000 & 3.6630 \\ \text { O(5)-S(2)-O(3)-Lp(8) } & 142.421 & 0.0000 & 10.0000 & 0.0000 & 3.7193 \\ \text { O(6)-S(2)-O(3)-Lp(7) } & 37.528 & 0.0000 & 10.0000 & 0.0000 & 3.7107 \\ \text { O(6)-S(2)-O(3)-Lp(8) } & -142.805 & 0.0000 & 10.0000 & 0.0000 & 3.6545 \\ \text { O(3)-S(2)-O(4)-Lp(9) } & -179.472 & 0.0000 & 10.0000 & 0.0000 & 0.0008 \\ \text { O(3)-S(2)-O(4)-Lp(10) } & 0.215 & 0.0000 & 10.0000 & 0.0000 & 0.0001 \\ \text { O(5)-S(2)-O(4)-Lp(9) } & 37.620 & 0.0000 & 10.0000 & 0.0000 & 3.7261 \\ \text { O(5)-S(2)-O(4)-Lp(10) } & -142.693 & 0.0000 & 10.0000 & 0.0000 & 3.6733\end{array}$




\begin{tabular}{|c|c|c|c|c|c|c|}
\hline \multirow{2}{*}{\multicolumn{2}{|c|}{$\begin{array}{l}\mathrm{O}(6)-\mathrm{S}(2)-\mathrm{O}(4)-\mathrm{Lp}(9) \\
\mathrm{O}(6)-\mathrm{S}(2)-\mathrm{O}(4)-\mathrm{Lp}(10)\end{array}$}} & -35.711 & \multicolumn{2}{|l|}{$\begin{array}{lll}0.0000 & 10.0000\end{array}$} & \multicolumn{2}{|c|}{$0.0000 \quad 3.4069$} \\
\hline & & & $0.0000 \quad 10.000$ & & 0.00003 & \\
\hline Atoms & Charge1 & Charge2 & $2 \quad \mathrm{R}$ & & $\mathrm{EC}$ & \\
\hline $\operatorname{Mg}(1)-\mathrm{O}(5)$ & 2.000 & -1.000 & 1.5601 & & -283.796 & \\
\hline $\mathrm{Mg}(1)-\mathrm{O}(6)$ & 2.000 & -1.000 & 1.5521 & & -285.245 & \\
\hline Atoms & Ion & Charge & Dipole & MU & R12(A) & ECD \\
\hline $\mathrm{Mg}(1)-\mathrm{O}(3)-\mathrm{S}($ & 2) $M g(1)$ & 2.000 & $\mathrm{O}(3)-\mathrm{S}(2)$ & 2.930 & 3.0440 & 19.418 \\
\hline $\mathrm{Mg}(1)-\mathrm{O}(4)-\mathrm{S}($ & 2) $\operatorname{Mg}(1)$ & 2.000 & $\mathrm{O}(4)-\mathrm{S}(2)$ & 2.930 & 2.9549 & 17.296 \\
\hline $\operatorname{Mg}(1)-\operatorname{Lp}(7)-C$ & (3) $\operatorname{Mg}(1)$ & 2.000 & $\mathrm{Lp}(7)-\mathrm{O}(3)$ & 0.900 & 3.6448 & 1.879 \\
\hline $\operatorname{Mg}(1)-\operatorname{Lp}(8)-C$ & (3) $\operatorname{Mg}(1)$ & 2.000 & $\mathrm{Lp}(8)-\mathrm{O}(3)$ & 0.900 & 3.8632 & 5.552 \\
\hline $\operatorname{Mg}(1)-\operatorname{Lp}(9)-C$ & (4) $\operatorname{Mg}(1)$ & 2.000 & $\mathrm{Lp}(9)-\mathrm{O}(4)$ & 0.900 & 3.4261 & 0.634 \\
\hline $\operatorname{Mg}(1)-\operatorname{Lp}(10)$ & $\mathrm{O}(4) \operatorname{Mg}(1)$ & 2.000 & $\mathrm{Lp}(10)-\mathrm{O}(4)$ & 0.900 & 3.7117 & 6.011 \\
\hline $\begin{array}{l}\text { The total energ } \\
\text { Calculation en }\end{array}$ & $\begin{array}{l}\text { y for this frame: } \\
\text { ed }\end{array}$ & -255.908 & $8 \mathrm{kcal} / \mathrm{mol}$ & & & \\
\hline
\end{tabular}

Magnesium Sulfat $\left(\mathrm{MgSO}_{4}\right)$ ialah senyawa ion yang mempunyai ikatan ionik yang terbentuk dengan kecenderungan atom $\mathrm{Mg}$ melepas elektron dan molekul $\mathrm{SO}_{4}$ menangkap electron agar tercapai konfigurasi gas mulia. Magnesium cenderung melepaskan elektron dan menjadi ion positif sedangkankelompok atom sulfat, cenderung menangkap elektron dan menjadi ion negatif $(11 ; 46-48 ; 212 ; 213)$.

Magnesium yang memiliki nomor atom 12, memiliki konfigurasi elektron (berdasarkan kulit atom) yaitu :

\begin{tabular}{|lll} 
K & L & M \\
2 & 8 & 2
\end{tabular}

Untuk menuju stabil, magnesium melepaskan dua elektronnya. Sedangkan molekul sulfat memiliki dua eletron yang belum berpasangan yakni pada 2 atom $\mathrm{O}$ dengan struktur anionnya :<smiles>O=S(=O)([O-])[O-]</smiles>

Gambar 13. Anion Sulfat

Untuk stabil, anion sulfat harus menangkap 2 elektron dari atom lain yakni pada senyawa ini adalah eletron dari kation magnesium.

Penggambaran ikatan ionik pada senyawa $\mathrm{MgSO}_{4}$ seperti berikut

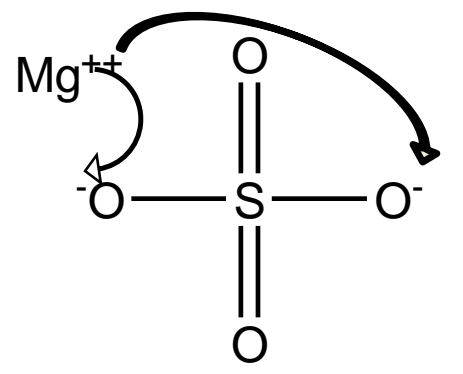

Gambar 14. Ikatan Ionik pada Senyawa $\mathrm{MgSO}_{4}$ 
Molekul sulfat menangkap elektron yang dilepaskan oleh atom magnesium dan menjadi anion sulfat. Akibat perbedaan muatan ion magnesium dan ion sulfat menghasilkan terikat kuat atau gaya elektrostatis antara keduanya ${ }^{(214)}$.

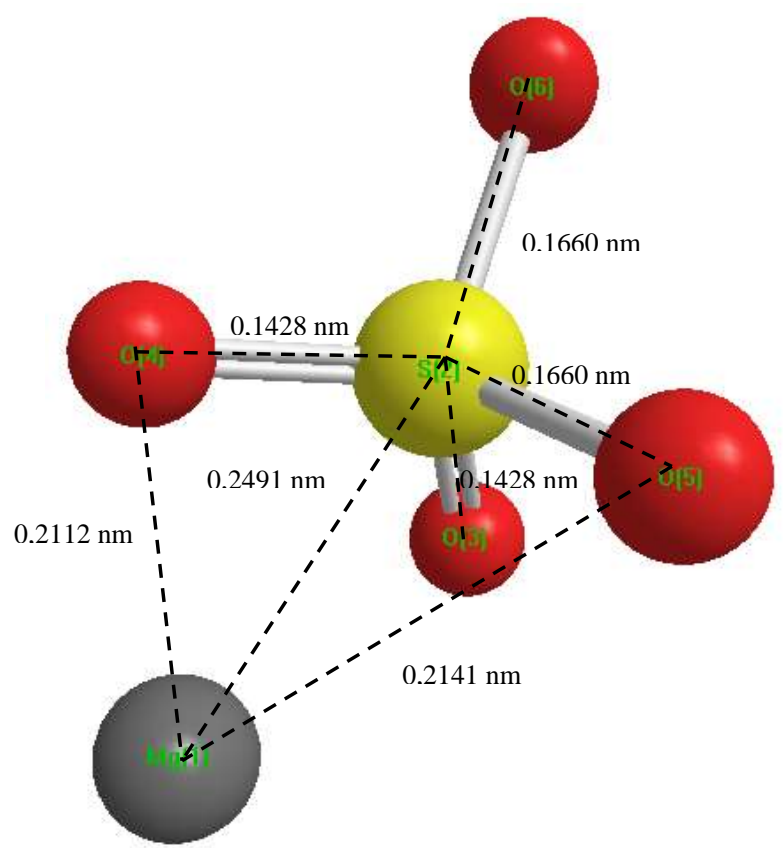

Gambar 15. Panjang masing-masing ikatan pada Senyawa $\mathrm{MgSO}_{4}$

Pelarutan garam magnesium sulfat ke dalam air akan menyebabkan pemisahan ion. Hal ini disebabkan oleh adanya pengaruh kepolaran air terhadap gaya elektrostatik dalam senyawa ion sehingga ion dapat larut dalam air ${ }^{(215)}$. Alasan inilah yang menyebabkan $\mathrm{MgSO}_{4}$ hanya dapat larut dalam senyawa polar lainnya. Setelah dilarutkan, maka ion-ion akan bergerak dalam larutan. Ion akan dikelilingi oleh molekul air yang telah terprotonasi $\left(\mathrm{H}_{3} \mathrm{O}^{+}\right)^{(216)}$.
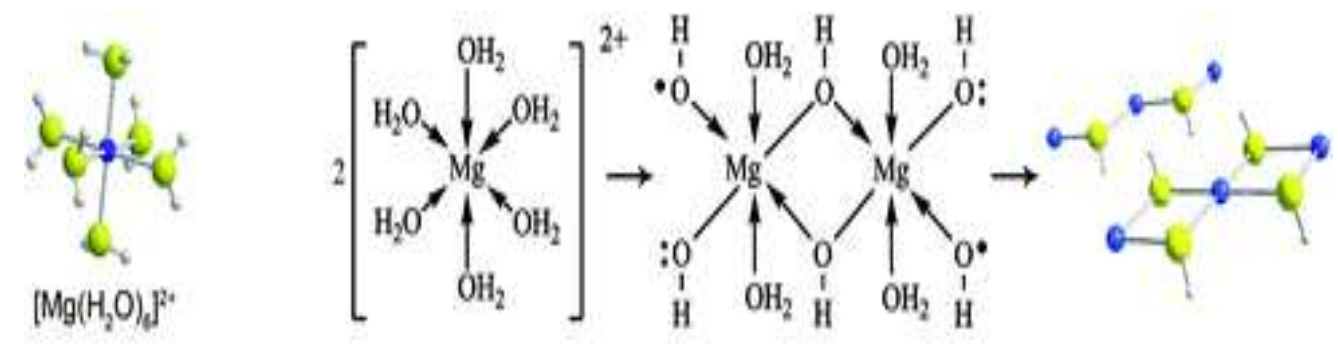

Gambar 16. Solvasi ion Magnesium

$\mathrm{MgSO}_{4}$ merupakan salah satu senyawa yang terion dalam air dan termasuk elektrolit kuat. Ion-ion ${ }^{(217)}$ dari senyawa ini akan bergerak didalam air dan dapat menghantarkan listrik jika dihubungkan dengan alat yang dapat mengubah energi kimia menjadi energi listrik. $\mathrm{MgSO}_{4}$ ter-ion sempurna dalam air sehingga merupakan elektrolit kuat ${ }^{(218)}$. Ada beberapa parameter yang menyebabkan ion dari $\mathrm{MgSO}_{4}$ ini dapat menghantarkan listrik dan bagaimana gerakan ion ini.

\subsection{Konduktivitas}

Konduktivitas $^{(210 ;}$ 219-221) adalah proses pergerakan ion akibat pengaruh medan listrik (E) . Karena adanya pergerakan ion tersebut, larutan dapat menghasilkan listrik. 
Kemampuan suatu larutan dalam mengantarkan listrik disebut konduktivitas listrik. Arus listrik di hantarkan oleh ion ion yang terkandung didalam larutan sehingga konduktivitas listrik hanya memperhitungkan jumlah/konsentrasi ion pada larutan. Ion memiliki karakteristik tersendiri dalam menghantarkan arus listrik ${ }^{(222-225)}$. Maka dari itu nilai konduktivitas listrik hanya menunjukkan konsentrasi ion total dalam larutan. Banyaknya ion di dalam larutan juga dipengaruhi oleh padatan terlarut di dalamnya ${ }^{(226)}$.

Begitu pula dengan larutan magnesium sulfat juga memiliki nilai konduktivitas. Besarnya konduktivitas ini ditentukan oleh jumlah konsentrasi elektrolit. Energi listrik dapat ditransfer melalui materi berupa hantaran yang bermuatan listrik yang berwujud arus listrik yang berarti bahwa harus ada pembawa muatan listrik di dalam materi serta adanya gaya yang menggerakkan pembawa muatan tersebut ${ }^{(227-231)}$. Pembawa muatan dapat berupa elektron atau dapat juga digunakan ion positif dan ion negatif dalam larutan elektrolit dan leburan garam $^{(232)}$. Gaya listrik yang membuat muatan bergerak biasanya berasal dari sumber energi listrik. Arus listrik akan mengalir atau berpindah dari tempat yang berpotensial tinggi menuju tempat dengan potensial yang lebih rendah. Arus listrik terjadi didalam suatu larutan karena adanya ion-ion yang bergerak ${ }^{(233-235)}$.

Berikut data hasil percobaan konduktivitas yang dialami oleh larutan $\mathrm{MgSO}_{4}$ :

\begin{tabular}{ll}
\hline $\begin{array}{c}\text { Konsentrasi } \mathrm{MgSO}_{4} \text { dalam } \\
\text { persen massa }\end{array}$ & Konduktivitas $\left({\left.\mathrm{mS} . \mathrm{cm}^{-1}\right)}^{-1}\right.$ \\
\hline $0,5 \%$ & 4,1 \\
$1 \%$ & 7,6 \\
$2 \%$ & 13,3 \\
$5 \%$ & 27,4 \\
$10 \%$ & 42,7 \\
$15 \%$ & 54,2 \\
\hline
\end{tabular}

Tabel 8. Nilai Konduktivitas larutan $\mathrm{MgSO}_{4}$ berdasarkan Konsenterasi Persen Massa

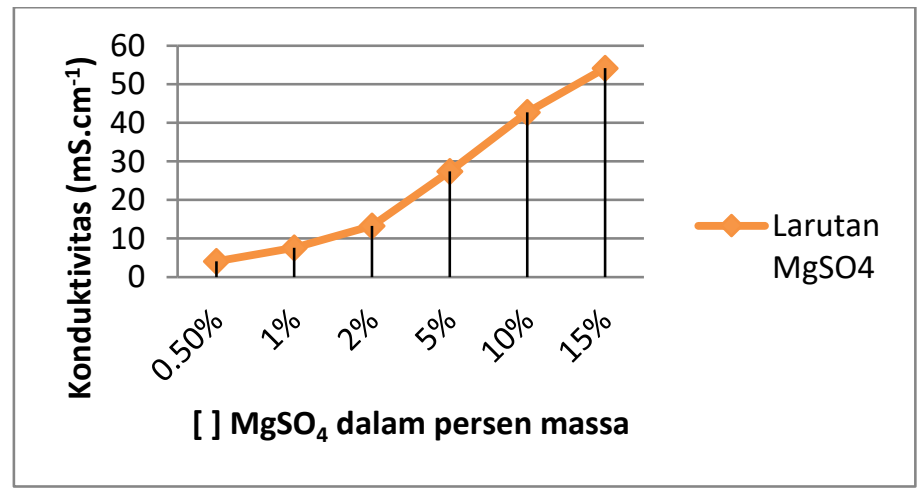

Tabel 9. Grafik konduktivitas terhadap konsenterasi $\mathrm{MgSO}_{4}$

Dari tabel dan grafik diatas dapat disimpulkan bahwa semakin besar konsentrasi larutan magnesium sulfat maka konduktivitasnya juga semakin besar ${ }^{(236)}$.

Konduktivitas dapat dihitung dengan menggunakan rumus berikut( ${ }^{(237-240)}$,

$$
K=\frac{1}{P}\left(\Omega^{-1} \mathrm{~cm}^{-1}\right)
$$


Konduktivitas biasanya tersedia dalam S Cm${ }^{-1}$ dan konsentrasi dalam M. Sehingga hubungan praktisnya jika diketahui dalam $\mathrm{mho} / \mathrm{cm}$ adalah :

$$
\begin{aligned}
\mathrm{R} & =\rho \times \frac{l}{\mathrm{~A}} . \\
k & =\frac{1}{\mathrm{RA}} \ldots \ldots
\end{aligned}
$$

$$
\Lambda \mathrm{m}=\frac{100 \times \frac{K}{\left(\mathrm{scm}^{-1}\right) \mathrm{S}} \mathrm{Cm}^{2} \mathrm{~mol}^{-1}}{c / M}
$$

$\mathrm{H}_{2} \mathrm{O}$ adalah penghantar buruk, $l \mathrm{H}_{2} \mathrm{O}=5 \times{ }^{10-8} \mathrm{mho} / \mathrm{cm}$ pada $25^{\circ} \mathrm{C}$ dan $\rho \mathrm{MgSO}_{4}=2.66$ $\mathrm{g} / \mathrm{cm}^{3}$ (anhidrat)

\subsection{Mobilitas Ion}

Mobilitas ion ${ }^{(66 ; 67 ; 241)}$ adalah kecepatan ion pada beda potensial antara kedua elektroda. Mobilitas ion merupakan perbandingan antara laju dan kuat medan.

$$
\mu=\frac{v}{E}
$$

Mobilitas ion juga dapat dihitung menggunakan pengukuran sebenarnya antara jarak yang di tempuh setiap ion dengan waktu yang diperlukannya untuk menempuh jarak

$$
\mu=\frac{x}{\Delta t}
$$

Mobilitas ion dapat dihitung dengan pengukuran sebenarnya jarak yang ditempuh setiap ion dalam waktu tertentu dengan metode batas bergerak ${ }^{(242)}$.

$$
U=\frac{x}{t\left(\frac{d E}{d x}\right)}
$$

$\mathrm{x}=\operatorname{jarak}(\mathrm{m}) \mathrm{t}=$ waktu $(\mathrm{dt})\left(\frac{d E}{d x}\right)=$ kekuatan medan $\left(\right.$ volt. $\left.\mathrm{m}^{-1}\right)$

$$
E=\frac{d E}{d x}=\frac{I}{A L_{s}}
$$

Maka

$$
U=\frac{\lambda_{m}}{z F}
$$

$\mathrm{Z}=$ valensi kation $\mathrm{F}=$ Faraday

\begin{tabular}{cc}
\hline Ion & $\begin{array}{c}\text { Mobilitas Ionik } \\
\left(10^{-8} \mathrm{~m}^{2} \mathrm{~s}^{-1} \mathrm{~V}^{-1}\right)\end{array}$ \\
\hline $\mathrm{Mg}^{2+}$ & 5,50 \\
$\mathrm{SO}_{4}^{2-}$ & 8,29 \\
$\mathrm{~K}^{+}$ & 7,62
\end{tabular}




\begin{tabular}{cr}
$\mathrm{Na}^{+}$ & 5,19 \\
$\mathrm{Cl}^{-}$ & 7,91 \\
$\mathrm{NO}_{3}^{-}$ & 7,40 \\
$\mathrm{~F}^{-}$ & 5,70 \\
\hline Tabel 10. Mobilitas Ionik dalam air pada suhu $298 \mathrm{~K}$
\end{tabular}

\subsection{Kecepatan Hanyut}

Untuk menahan partikel bermuatan agar kecepatan rata-rata tetap digunakan kecepatan hanyut. Kecepatan hanyut ${ }^{(243-247)}$ mempunyai arah sama dengan medan listrik dan hubungan keduanya dinyatakan dalam suatu konstanta yang disebut dengan mobilitas.

Gaya yang disebabkan oleh medan listrik.

$$
F=Z e . E
$$

Jika dua elektroda yang terpisah dengan jarak 1 berada pada selisih potensial $(\Delta \phi)$, maka ion dalam larutan diantara kedua elektroda tersebut, mengalami medan listrik (E) sebesar

$$
E=\frac{\Delta \phi}{l} .
$$

$$
E=\frac{\text { selisih potensial }}{\text { dua elektroda yang terpisah dengan jarak }}
$$

Maka

$$
F=z e E=\frac{z e \Delta \phi}{l}
$$

Gaya tersebut dipengaruhi juga oleh gaya Viskos (kekentalan) yang dirumuskan oleh persamaan Stokes:

$$
\mathrm{F}=6 \pi \eta r v .
$$

Dimana: : viskositas

$$
\begin{aligned}
& r: \text { jari-jari } \\
& v: \text { kecepatan } \\
& Z e: \text { muatan masing-masing ion }
\end{aligned}
$$

Jika diabaikan efek penghambat lain, maka laju maksimum:

$$
v=\frac{Z e . E}{6 \pi \eta r v}=\mu . E .
$$

Dimana: : mobilitas ion (koefisien perbandingan antara laju dan kuat medan).

Sedangkan gaya perlambatan (F'), sedangkan gaya gesek (f) maka :

$$
\begin{aligned}
F^{\prime} & =f s \\
\mathrm{f} & =6 \pi \eta a
\end{aligned}
$$


Kedua gaya ini bekerja dalam arah yang berlawanan dan ion mencapai kecepatan akhir, yaitu kecepatan hanyut ion (s), jika gaya mempercepat $\mathrm{F}$ diimbangi oleh gaya perlambatan F'. Gaya neto menjadi nol $\left(\mathrm{F}=\mathrm{F}^{\prime}\right)$ jika :

$$
s=\frac{z e E}{f}
$$

Jika potensial $\mathrm{MgSO}_{4}$ adalah 9,0 V dan jarak antar elektroda adalah $9 \mathrm{~cm}$, maka kecepatan hanyutnya dapat dihitung dengan rumus

$$
\begin{gathered}
E=\frac{\Delta \phi,}{\iota} \\
E=\frac{9}{9}=1 \mathrm{~V} / \mathrm{cm}
\end{gathered}
$$

\subsection{Bilangan transpor}

Fraksi dari arus total yang dibawa oleh ion jenis tertentu. Untuk larutan dengan 2 jenis ion, bilangan transport kation :

$$
t_{+}=\frac{I^{+}}{I} \quad I=t_{+}+t_{+} \quad \mathrm{I}=\text { arus total }
$$

Bilangan transport pembatas ${ }^{(162 ; 248 ; 249)}\left(\mathrm{t}^{0}\right)$ untuk limit konsentrasi nol dari larutan elektrolit.

Jika $I \infty K$ sehingga :

$$
t^{0}=\frac{z v u}{\sum_{i} z v u_{i}}
$$

Untuk elektrolit simetris (bilangan muatan untuk kedua ion sama) maka persamaan diatas disederhanakan :

$$
t^{0}=\frac{u}{\sum_{i} u_{i}}
$$

Hubungan antara konduktivitas ion dengan mobilitas ion :

Jadi untuk setiap jenis ion :

$$
t^{0}=\frac{v \lambda}{\sum_{i} v_{i} \lambda_{i}}=\frac{v \lambda}{\Lambda^{0}{ }_{m}}
$$

$$
v \lambda=t^{0} \Lambda^{0}{ }_{m}
$$

Penentuan Bilangan Transport :

1.1. Metode Hittorf

Prinsip : Menentukan perubahan konsentrasi elektrolit disekitar elektroda yang disebabkan karena migrasi ion.

1.2. Metoda perbatasan bergerak 
Sel Hittorf : seperangkat alat elektrolisis yang terdiri atas pesawat Hittorf, sepasang elektroda, dan sumber tegangan arus searah

\subsection{Hantaran Ion}

Hantaran molar ion ${ }^{(250-253)}$ pada pengenceran tidak berhingga adalah :

$$
\begin{aligned}
& v^{+} \lambda^{0+}=\left(t_{+}\right)^{0} \Lambda \\
& v^{-} \lambda^{0-}=\left(t_{-}\right)^{0} \Lambda
\end{aligned}
$$

Dimana $\left(t_{+}\right)^{0}=$ bilangan transport ion sampai pengenceran tak hingga

$\left(v^{+}\right)=$jumlah ion yang muatan positif

\section{Tinjauan Termodinamika}

Tinjauan secara termodinamika ${ }^{(254-260)}$ ialah untuk mengetahui sifat reaksi (eksotermis/endotermis). Untuk menentukan reaksi eksotermis atau endotermis, panas reaksi dapat dihitung dengan perhitungan panas pembentukan standar $\left(\Delta \mathrm{Hf}^{\circ}\right.$ pada $\mathrm{P}=1$ atm dan $\left.\mathrm{T}=25^{\circ} \mathrm{C}\right)$.

\begin{tabular}{ccc}
\hline Komponen & $\Delta \mathrm{Hf}^{\circ}, \mathrm{Kkal} / \mathrm{mol}$ & $\Delta \mathrm{Gf}^{\circ}, \mathrm{Kkal} / \mathrm{mol}$ \\
\hline $\mathrm{MgO}$ & $-143,84$ & $-143,73$ \\
$\mathrm{H}_{2} \mathrm{SO}_{4}$ & $-193,69$ & $-164,93$ \\
$\mathrm{MgSO}_{4}$ & $-304,94$ & $-277,7$ \\
$\mathrm{H}_{2} \mathrm{O}$ & $-57,7979$ & $-56,6899$ \\
\hline
\end{tabular}

Tabel 11. Harga $\Delta \mathrm{Hf}^{\circ}$ dan $\Delta \mathrm{Gf}^{\circ}$

Panas reaksi standar $\left(\Delta \mathrm{Hr}^{\circ}\right)$

$\Delta \mathrm{Hr}^{\circ}=\Sigma \Delta \mathrm{Hf}^{\circ}$ produk $-\Sigma \Delta \mathrm{Hf}^{\circ}$ reaktan

$\Delta \mathrm{Hr}^{\circ}=\left(\Delta \mathrm{Hf}^{\circ} \mathrm{MgSO}_{4}+\Delta \mathrm{Hf}^{\circ} \mathrm{H}_{2} \mathrm{O}\right)-\left(\Delta \mathrm{Hf}^{\circ} \mathrm{MgO}+\Delta \mathrm{Hf}^{\circ} \mathrm{H}_{2} \mathrm{SO}_{4}\right)$

$\Delta \operatorname{Hr}^{\circ}=[(-304,94)+(-57,7979)]-[(-143,84)+(-193,69)]$

$\Delta \mathrm{Hr}^{\circ}=-24,9879 \mathrm{Kkal} / \mathrm{mol}$

Karena $\Delta \mathrm{Hr}^{\circ}$ bernilai negatif maka reaksi bersifat eksotermis.

Kegunaan dari senyawa magnesium sulfat ${ }^{(13 ; 132-137 ; 139 ; 261)}$ dalam kehiudpan sehari hari. Anhidrat magnesium sulfat digunakan sebagai agen pengeringan. Karena bentuk anhidrat adalah higroskopis (mudah menyerap air dari udara). Magnesium sulfat dapat dimanfaatkan baik secara eksternal maupun internal. Magnesium sulfat oral digunakan untuk laksatif air asin atau purgatif osmotik. Magnesium sulfat merupakan sediaan utama magnesium intravena yakni melalui urat nadi.

Khasiat untuk penggunaan internal antara lain adalah ; Dalam bidang farmasi, diantaranya sebagai bahan Terapi untuk penyakit hipomagnesemia. Magnesium sulfat merupakan senyawa yang berperan sebagai agen antiaritmik dalam serangan jantung. Magnesium sulfat ini juga berperan sebagai bronkodilator setelah semua zat yang berperan sebagai beta-agonist dan antikolinergis telah dicoba sebelumnya. Senyawa magnesium sulfat dapat dinebulisasi untuk mengurangi gejala asma akut dan dapat dipakai dalam mengobati eklamsia pada wanita hamil. Senyawa ini ternyata juga dapat digunakan dalam menunda proses persalinan dengan jalan menghambat adanya kontraksi otot uterus pada kasus persalinan prematur. Magnesium sulfat intravena dimanfaatkan dalam mencegah cerebral palsy pada bayi prematur. Larutan garam sulfat seperti garam Epsom bisa diberikan sebagai bantuan pertama untuk keracunan barium klorida. 
Pemanfaatan senyawa magnesium sulfat dalam pertanian, antara lain ; digunakan dalam memperbaiki kekurangan jumlah unsur magnesium atau belerang pada tanah, nyatanya magnesium ialah unsur penting di dalam molekul klorofil, dan sulfur sebagai makronutrien krusial lainnya. Larutan magnesium sulfat hampir mendekati $\mathrm{pH}$ netral, oleh karenanya penggunaannya tidak mengubah $\mathrm{pH}$ tanah secara berlebihan.

Senyawa magnesium sulfat anhidrat biasanya digunakan sebagai desiccant dalam proses sintesis senyawa organik. Hal tersebut dikarenakan oleh afinitas molekulnya yang kuat dengan air. Magnesium sulfat juga dapat digunakan sebagai garam mandi yakni dalam terapi flotasi dan efektif membuat tubuh terasa ringan. Secara tradisional, juga digunakan untuk menenangkan kaki yang terasa sakit.

Magnesium sulfat digunakan secara parsial dalam beberapa kosmetik, biasanya untuk mencegah kerutan kulit sementara akibat perendaman ekstremitas di dalam air murni karena kemampuannya dalam peningkatan kekuatan ion dan dapat terserap ke dalam kulit untuk mengurangi peradangan. Magnesium sulfat boleh juga digunakan sebagai koagulan dalam proses pembuatan tahu. Magnesium sulfat heptahidrat juga dimanfaatkan dalam mempertahankan jumlah konsentrasi ion magnesium dalam perairan. Pada akuarium laut magnesium dimanfaatkan untuk menstabilkan ion-ion dalam air laut dan menghalangi proses pengendapan.

Magnesium sulfat digunakan untuk membuat tembaga sulfat dan berperan sebagai elektrolit. Larutan magnesium sulfat dielektrolisis dengan anoda tembaga sehingga terbentuk senyawa tembaga sulfat, magnesium hidroksida, dan hidrogen:

$$
\mathrm{Cu}_{(\mathrm{s})}+\mathrm{MgSO}_{4(\mathrm{~s})}+2 \mathrm{H}_{2} \mathrm{O}_{(\mathrm{l})} \rightarrow \mathrm{CuSO}_{4(\mathrm{aq})}+\mathrm{Mg}(\mathrm{OH})_{2(\mathrm{aq})}+\mathrm{H}_{2(\mathrm{~g})}
$$

\section{Kesimpulan}

Senyawa magnesium sulfat ialah senyawa suatu garam yang memiliki ikatan ion antara ion magnesium dengan ion sulfat dan di dalam molekul sulfat terdapat ikatan kovalen antara atom sulfur dan atom oksigen. Umumnya magnesium sulfat terbentuk dalam keadaan hidrat karena bentuk anhidratnya sangat higroskopis. Magnesium sulfat memiliki sifat termokimia dalam fasa solid dengan $\Delta H f, \Delta G f, S^{\circ}$, dan $C p$ pada tekanan 1 atm dan suhu $25^{\circ} \mathrm{C}$ yang masing-masing mempunyai nilai $-1284,9 \mathrm{~kJ} / \mathrm{mol},-1170,7 \mathrm{~kJ} / \mathrm{mol}, 91,6$ $\mathrm{J} / \mathrm{molK}$ dan 96,48 J/molK. Konduktivitas dari senyawa $\mathrm{MgSO}_{4}$ semakin meningkat seiring meningkatnya konsentrasi larutan elektrolit. Mobilitas ion $\mathrm{Mg}^{2+}$ dan $\mathrm{SO}_{4}{ }^{2-}$ adalah 5,50.10${ }^{8} \mathrm{~m}^{2} \mathrm{~s}^{-1} \mathrm{~V}^{-1}$ dan $8,29.10^{-8} \mathrm{~m}^{2} \mathrm{~s}^{-1} \mathrm{~V}^{-1}$. Panas reaksi standar $\left(\Delta \mathrm{Hr}^{\circ}\right) \mathrm{MgSO}_{4}$ bernilai negatif maka reaksi bersifat eksotermis. Banyak bidang yang memanfaatkan senyawa magnesium sulfat, diantaranya bidang farmasi, pertanian, sintesis bahan, koagulan, kosmetik. Sedangkan magnesium sulfat anhidrat digunakan sebagai pengering karena sifat higroskopisnya.

\section{Referensi}

1. Arsa G, Lanza FC, Cambri LT, Antonio EL, Murad N, et al. 2018. Predicted Equation for VO2 Based on a 20-Meter Multistage Shuttle Run Test for Children. International journal of sports medicine

2. Molina Molina DA, Guerra-Duarte C, Naves de Souza DL, Costal-Oliveira F, Avila GR, et al. 2018. Identification of a linear B-cell epitope in the catalytic domain of bothropasin, a metalloproteinase from Bothrops jararaca snake venom. Molecular immunology 104:20-6

3. Macedo PD, Corbi ST, de Oliveira G, Perussi JR, Ribeiro AO, Marcantonio RAC. 2018. Hypericin-glucamine antimicrobial photodynamic therapy in the 
progression of experimentally induced periodontal disease in rats. Photodiagnosis and photodynamic therapy

4. Lim J, Lawless HT. 2005. Qualitative differences of divalent salts: multidimensional scaling and cluster analysis. Chemical senses 30:719-26

5. Yoshii K, Kurihara K. 1983. Role of cations in olfactory reception. Brain research 274:239-48

6. Vasylevskyi S, Holzheu A, Fromm KM. 2018. Solid-state structure and antimicrobial and cytotoxicity studies of a cucurbit[6]uril-like Cu6L4 constructed from 3,5-bis[(1H-tetrazol-5-yl)methyl]-4H-1,2,4-triazol-4-amine. Acta crystallographica. Section C, Structural chemistry 74:1413-9

7. Popugaeva D, Kreyman K, Ray AK. 2018. Study of aluminium in groundwater using chemometric methods. Environmental technology:1-24

8. Takata T, Kimura J, Ihara H, Hatano N, Tsuchiya Y, Watanabe Y. 2018. Redox regulation of $\mathrm{Ca}(2+) /$ calmodulin-dependent protein kinase IV via oxidation of its active-site cysteine residue. Free radical biology \& medicine

9. Park JH, Wang JJ, Zhou B, Mikhael JER, DeLaune RD. 2018. Removing mercury from aqueous solution using sulfurized biochar and associated mechanisms. Environmental pollution 244:627-35

10. Becana M, Wienkoop S, Matamoros MA. 2018. Sulfur Transport and Metabolism in Legume Root Nodules. Frontiers in plant science 9:1434

11. Zhang Y, Li T, Hou D, Zhang J, Jiang J. 2018. Insights on magnesium and sulfate ions' adsorption on the surface of sodium alumino-silicate hydrate (NASH) gel: a molecular dynamics study. Physical chemistry chemical physics : PCCP 20:18297310

12. Saladino R, Botta G, Bizzarri BM, Di Mauro E, Garcia Ruiz JM. 2016. A Global Scale Scenario for Prebiotic Chemistry: Silica-Based Self-Assembled Mineral Structures and Formamide. Biochemistry 55:2806-11

13. Walling SA, Provis JL. 2016. Magnesia-Based Cements: A Journey of 150 Years, and Cements for the Future? Chemical reviews 116:4170-204

14. Zhang M, Huang G, Zhang X, Lin Z, Li Y, et al. 2018. Inexpensive Weight-Reducing Aid (L-Carnitine) as An Efficient Catalyst for Synthesis of Benzimidazoles. Combinatorial chemistry \& high throughput screening

15. Abbasnezhad A, Niazmand S, Mahmoudabady M, Rezaee SA, Soukhtanloo M, et al. 2018. Nigella sativa L. seed regulated eNOS, VCAM-1 and LOX-1 genes expression and improved vasoreactivity in aorta of diabetic rat. Journal of ethnopharmacology 228:142-7

16. Lee H, Kimura S, Iwata T. 2018. Lipase-Catalyzed Regioselective Synthesis of Dextrin Esters. Biomacromolecules

17. Qi H, Han S, Lu M, Yin Z, Yan H, et al. 2018. [Simultaneous determination of 18 food-borne stimulant drug residues in beef using ultra-high performance liquid chromatography-tandem mass spectrometry]. Se $p u=$ Chinese journal of chromatography 36:621-8

18. Dun J, Osei-Yeboah F, Boulas P, Lin Y, Sun CC. 2018. A systematic evaluation of dual functionality of sodium lauryl sulfate as a tablet lubricant and wetting enhancer. International journal of pharmaceutics 552:139-47

19. Becker SM, Job KM, Lima K, Forbes TJ, Wagstaff J, et al. 2018. Prospective study of serum and ionized magnesium pharmacokinetics in the treatment of children with severe acute asthma. European journal of clinical pharmacology

20. Shaw OEF, Yager JY. 2018. Preventing Childhood and Lifelong Disability: Maternal Dietary Supplementation for Perinatal Brain Injury. Pharmacological research 
21. Kale MA, Sonwane GM. 2018. Molecular Docking, G-QSAR studies, Synthesis and Anticancer screening of some New 2-Phenazinamines as Bcr-Abl Tyrosine kinase Inhibitors. Current drug discovery technologies

22. Gan M, Li J, Sun S, Ding J, Zhu J, et al. 2018. Synergistic effect between sulfide mineral and acidophilic bacteria significantly promoted $\mathrm{Cr}(\mathrm{VI})$ reduction. Journal of environmental management 219:84-94

23. Goodrich CA, Kita NT, Yin QZ, Sanborn ME, Williams CD, et al. 2017. Petrogenesis and Provenance of Ungrouped Achondrite Northwest Africa 7325 from Petrology, Trace Elements, Oxygen, Chromium and Titanium Isotopes, and Mid-IR Spectroscopy. Geochimica et cosmochimica acta 203:381-403

24. Wu CY, Kong M, Zhang W, Long F, Zhou J, et al. 2018. Impact of sulphur fumigation on the chemistry of ginger. Food chemistry 239:953-63

25. Johnson W, Jr., Bergfeld WF, Belsito DV, Hill RA, Klaassen CD, et al. 2018. Safety Assessment of Magnesium Sulfate as Used in Cosmetics. International journal of toxicology 37:47S-54S

26. Vela-Soria F, Iribarne-Duran LM, Mustieles V, Jimenez-Diaz I, Fernandez MF, Olea N. 2018. QuEChERS and ultra-high performance liquid chromatography-tandem mass spectrometry method for the determination of parabens and ultraviolet filters in human milk samples. Journal of chromatography. A 1546:1-9

27. Kachhawaha AS, Nagarnaik PM, Jadhav M, Pudale A, Labhasetwar PK, Banerjee K. 2017. Optimization of a Modified QuEChERS Method for Multiresidue Analysis of Pharmaceuticals and Personal Care Products in Sewage and Surface Water by LCMS/MS. Journal of AOAC International 100:592-7

28. Wang M, Qiao J, Yu C, Chen H, Sun C, et al. 2018. The auxin influx carrier, OsAUX3, regulates rice root development and responses to aluminium stress. Plant, cell \& environment

29. Pal A, Nasker P, Paul S, Roy Chowdhury A, Sinha A, Das M. 2018. Strontium doped hydroxyapatite from Mercenaria clam shells: Synthesis, mechanical and bioactivity study. Journal of the mechanical behavior of biomedical materials 90:328-36

30. Mestre AS, Hesse F, Freire C, Ania CO, Carvalho AP. 2018. Chemically activated high grade nanoporous carbons from low density renewable biomass (Agave sisalana) for the removal of pharmaceuticals. Journal of colloid and interface science 536:681-93

31. Zhang J, Sheng X, Cheng X, Chen L, Jin J, Feng X. 2017. Robust electrochemical metal oxide deposition using an electrode with a superhydrophobic surface. Nanoscale 9:87-90

32. Xu JZ, Zhang WG. 2017. Menaquinone-7 production from maize meal hydrolysate by Bacillus isolates with diphenylamine and analogue resistance. Journal of Zhejiang University. Science. B 18:462-73

33. Wang F, Hou TZ, Li JJ, Li ZZ, Tang CF. 2016. [Effect of magnesium and selenium on the expression of matrix metalloproteinases-20 and kallikrein 4 in fluorosis mice]. Zhonghua kou qiang yi xue za zhi = Zhonghua kouqiang yixue zazhi = Chinese journal of stomatology 51:546-51

34. Gen M, Huang DD, Chan CK. 2018. Reactive Uptake of Glyoxal by AmmoniumContaining Salt Particles as a Function of Relative Humidity. Environmental science \& technology 52:6903-11

35. Teychene J, Roux-De Balmann H, Galier S. 2017. Role of the triple solute/ion/water interactions on the saccharide hydration: A volumetric approach. Carbohydrate research 448:118-27 
36. Than NN, Soe HHK, Palaniappan SK, Abas AB, De Franceschi L. 2017. Magnesium for treating sickle cell disease. The Cochrane database of systematic reviews 4:CD011358

37. Ran C, Chen D, Ma H, Jiang Y. 2017. Graphene oxide adsorbent based dispersive solid phase extraction coupled with multi-pretreatment clean-up for analysis of trace aflatoxins in traditional proprietary Chinese medicines. Journal of chromatography. B, Analytical technologies in the biomedical and life sciences 1044-1045:120-6

38. El-Shewy KM, Kunbaz A, Gad MM, Al-Husseini MJ, Saad AM, et al. 2018. Hyperbaric oxygen and aerobic exercise in the long-term treatment of fibromyalgia: A narrative review. Biomedicine \& pharmacotherapy= Biomedecine \& pharmacotherapie 109:629-38

39. Shams UI Hassan S, Jin HZ, Abu-Izneid T, Rauf A, Ishaq M, Suleria HAR. 2018. Stress-driven discovery in the natural products: A gateway towards new drugs. Biomedicine \& pharmacotherapy = Biomedecine \& pharmacotherapie 109:459-67

40. Hamid S, Abudanash D, Han S, Kim JR, Lee W. 2018. Strategies to enhance the stability of nanoscale zero-valent iron (NZVI) in continuous $\mathrm{BrO3}(-)$ reduction. Journal of environmental management 231:714-25

41. Schmitz T, Sentilhes L, Lorthe E, Gallot D, Madar H, et al. 2018. [Preterm Premature Rupture of Membranes: CNGOF Guidelines for Clinical Practice (Short version)]. Gynecologie, obstetrique, fertilite \& senologie

42. Gulson B, Mizon K, Taylor A, Wu M. 2018. Dietary zinc, calcium and nickel are associated with lower childhood blood lead levels. Environmental research 168:439-44

43. Cabeza O, Segade L, Dominguez-Perez M, Rilo E, Ausin D, et al. 2018. Mesostructure and physical properties of aqueous mixtures of the ionic liquid 1ethyl-3-methyl imidazolium octyl sulfate doped with divalent sulfate salts in the liquid and the mesomorphic states. Physical chemistry chemical physics : PCCP 20:8724-36

44. Yue F, Chen KL, Lu F. 2016. Low Temperature Soda-Oxygen Pulping of Bagasse. Molecules 21:85

45. Zheng XY, Yao J, Zhu JM, Li M, Qiu SQ, et al. 2015. [Effect of Magnesium Sulfate, Nifedipine Tablet Combined Salvia Injection on ET-1/NO, TXA2/PGI2 and Hemorheology of Preeclampsia Patients]. Zhongguo Zhong xi yi jie he za zhi Zhongguo Zhongxiyi jiehe zazhi = Chinese journal of integrated traditional and Western medicine 35:962-5

46. DePalma JW, Kelleher PJ, Johnson CJ, Fournier JA, Johnson MA. 2015. Vibrational Signatures of Solvent-Mediated Deformation of the Ternary Core Ion in SizeSelected [MgSO4Mg(H2O)n=4-11] $(2+)$ Clusters. The journal of physical chemistry. A 119:8294-302

47. Liu Y, Guo SX, Bond AM, Zhang J, Geletii YV, Hill CL. 2013. Voltammetric determination of the reversible potentials for $[\{\mathrm{Ru} 4 \mathrm{O} 4(\mathrm{OH}) 2(\mathrm{H} 2 \mathrm{O}) 4\}$ (gammaSiW10036)2]10- over the $\mathrm{pH}$ range of 2-12: electrolyte dependence and implications for water oxidation catalysis. Inorganic chemistry 52:11986-96

48. Grande A, Costas C, Benavente J. 2002. Subunit composition and conformational stability of the oligomeric form of the avian reovirus cell-attachment protein sigmaC. The Journal of general virology 83:131-9

49. Shao G, Agar J, Giese RW. 2017. Cold-induced aqueous acetonitrile phase separation: A salt-free way to begin quick, easy, cheap, effective, rugged, safe. Journal of chromatography. A 1506:128-33 
50. Sedlak M, Rak D. 2013. Large-scale inhomogeneities in solutions of low molar mass compounds and mixtures of liquids: supramolecular structures or nanobubbles? The journal of physical chemistry. B 117:2495-504

51. Hu LF, Feng HJ, Wu YY, Long YY, Wang J, Shen DS. 2010. A comparative study on stabilization of available As in highly contaminated hazardous solid waste. Journal of hazardous materials 174:194-201

52. Shen Z, Arimoto R, Cao J, Zhang R, Li X, et al. 2008. Seasonal variations and evidence for the effectiveness of pollution controls on water-soluble inorganic species in total suspended particulates and fine particulate matter from Xi'an, China. Journal of the Air \& Waste Management Association 58:1560-70

53. Mohamed S, van der Merwe EM, Altermann W, Doucet FJ. 2017. Addendum to "Process development for elemental recovery from PGM tailings by thermochemical treatment: Preliminary major element extraction studies using ammonium sulphate as extracting agent" [Waste Manage. 50 (2016) 334-345]. Waste management 66:222-4

54. Mohamed S, van der Merwe EM, Altermann W, Doucet FJ. 2016. Process development for elemental recovery from PGM tailings by thermochemical treatment: Preliminary major element extraction studies using ammonium sulphate as extracting agent. Waste management 50:334-45

55. McKinnon WB, Zolensky ME. 2003. Sulfate content of Europa's ocean and shell: evolutionary considerations and some geological and astrobiological implications. Astrobiology 3:879-97

56. Koli JM, Basu S, Nayak BB, Kannuchamy N, Gudipati V. 2011. Improvement of gel strength and melting point of fish gelatin by addition of coenhancers using response surface methodology. Journal of food science 76:E503-9

57. Atta HM, Abul-Hamd AT, Radwan HG. 2009. Production of destomycin-A antibiotic by Streptomyces sp. using rice straw as fermented substrate. Communications in agricultural and applied biological sciences 74:879-97

58. Leng CB, Pang SF, Zhang Y, Cai C, Liu Y, Zhang YH. 2015. Vacuum FTIR Observation on the Dynamic Hygroscopicity of Aerosols under Pulsed Relative Humidity. Environmental science \& technology 49:9107-15

59. Shoeibi S, Amirahmadi M, Yazdanpanah H, Pirali-Hamedani M, Pakzad SR, Kobarfard F. 2011. Effect of cooking process on the residues of three carbamate pesticides in rice. Iranian journal of pharmaceutical research : IJPR 10:119-26

60. Chou IM, Seal RR, 2nd. 2003. Determination of epsomite-hexahydrite equilibria by the humidity-buffer technique at $0.1 \mathrm{MPa}$ with implications for phase equilibria in the system MgSO4-H2O. Astrobiology 3:619-30

61. Eshleman AJ, Nagarajan S, Wolfrum KM, Reed JF, Swanson TL, et al. 2018. Structure-activity relationships of bath salt components: substituted cathinones and benzofurans at biogenic amine transporters. Psychopharmacology

62. Luetchford KA, Wung N, Argyle IS, Storm MP, Weston SD, et al. 2018. Next generation in vitro liver model design: Combining a permeable polystyrene membrane with a transdifferentiated cell line. Journal of membrane science 565:425-38

63. Wojciak KM, Stasiak DM, Ferysiuk K, Solska E. 2018. The influence of sonication on the oxidative stability and nutritional value of organic dry-fermented beef. Meat science 148:113-9

64. Yeung RA, Kennedy RA. 2018. A comparison of selected physico-chemical properties of calcium alginate fibers produced using two different types of sodium alginate. Journal of the mechanical behavior of biomedical materials 90:155-64 
65. Fanelli A, Sorella MC, Ghisi D. 2018. Morphine sulfate abuse-deterrent formulations for the treatment of chronic pain. Expert review of clinical pharmacology

66. Campuzano IDG, Sobott F, van Stipdonk MJ. 2018. Editorial and Review: 30th ASMS Sanibel Conference on Mass Spectrometry-Computational Modelling in Mass Spectrometry and Ion Mobility: Methods for Ion Structure and Reactivity Determination. Journal of the American Society for Mass Spectrometry

67. Dou M, Chouinard CD, Zhu Y, Nagy G, Liyu AV, et al. 2018. Nanowell-mediated multidimensional separations combining nanoLC with SLIM IM-MS for rapid, highpeak-capacity proteomic analyses. Analytical and bioanalytical chemistry

68. Pfitzner KS, Harford AJ, Whiteside TG, Bartolo RE. 2018. Mapping magnesium sulfate salts from saline mine discharge with airborne hyperspectral data. The Science of the total environment 640-641:1259-71

69. Jafari K, Asghari FB, Hoseinzadeh E, Heidari Z, Radfard M, et al. 2018. Groundwater quality assessment for drinking and agriculture purposes in Abhar city, Iran. Data in brief 19:1033-9

70. Zhang H, Ye K, Zhu K, Cang R, Yan J, et al. 2017. High-Energy-Density Aqueous Magnesium-Ion Battery Based on a Carbon-Coated FeVO4 Anode and a Mg-OMS1 Cathode. Chemistry 23:17118-26

71. Wu Z, Wang X, Chen Y, Cai Y, Deng J. 2018. Assessing river water quality using water quality index in Lake Taihu Basin, China. The Science of the total environment 612:914-22

72. Komaromy AZ, Kulsing C, Boysen RI, Hearn MT. 2015. Salts employed in hydrophobic interaction chromatography can change protein structure - insights from protein-ligand interaction thermodynamics, circular dichroism spectroscopy and small angle X-ray scattering. Biotechnology journal 10:417-26

73. Grevel KD, Majzlan J, Benisek A, Dachs E, Steiger M, et al. 2012. Experimentally determined standard thermodynamic properties of synthetic $\mathrm{MgSO}(4) .4 \mathrm{H}(2) \mathrm{O}$ (Starkeyite) and MgSO(4).3H(2)O: a revised internally consistent thermodynamic data set for magnesium sulfate hydrates. Astrobiology 12:1042-54

74. Afanas'ev VN. 2011. Solvation of electrolytes and nonelectrolytes in aqueous solutions. The journal of physical chemistry. B 115:6541-63

75. Mabry JC, Mondal K. 2011. Magnesian calcite sorbent for carbon dioxide capture. Environmental technology 32:55-67

76. Feng C, Wang J, Tang Q, Zhong Z, Qiao S, et al. 2018. One-pot synthesis of glycosyl phenylthiosulfonates from sulfinate, $\mathrm{S}$ and glycosyl bromides. Carbohydrate research 471:1-5

77. Vidyasagar A, Shi J, Kreitmeier P, Reiser O. 2018. Bromo- or Methoxy-GroupPromoted Umpolung Electron Transfer Enabled, Visible-Light-Mediated Synthesis of 2-Substituted Indole-3-glyoxylates. Organic letters

78. Fang J, Li L, Yang C, Chen J, Deng GJ, Gong H. 2018. Tandem Oxidative RingOpening/Cyclization Reaction in Seconds in Open Atmosphere for the Synthesis of 1-Tetralones in Water-Acetonitrile. Organic letters

79. Pickart CM, Jencks WP. 1984. Energetics of the calcium-transporting ATPase. The Journal of biological chemistry 259:1629-43

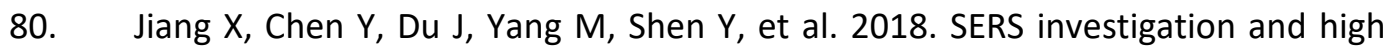
sensitive detection of carbenicillin disodium drug on the Ag substrate. Spectrochimica acta. Part A, Molecular and biomolecular spectroscopy 204:241-7

81. Timofeev VI, Sinitsyna EV, Kostromina MA, Muravieva TI, Makarov DA, et al. 2017. Crystal structure of recombinant phosphoribosylpyrophosphate synthetase 2 
from Thermus thermophilus HB27 complexed with ADP and sulfate ions. Acta crystallographica. Section F, Structural biology communications 73:369-75

82. Elmasry MS, Elazazy MS, El-Sayed HM. 2018. Multivariate analysis of tioconazole - TCNQ charge transfer interaction: Kinetics, thermodynamics and twofold response optimization. Spectrochimica acta. Part A, Molecular and biomolecular spectroscopy 202:401-9

83. Wei H, Wang Y, Yao J, Li H. 2018. Empirical study of physicochemical and spectral properties of $\mathrm{Cu}(\mathrm{II})$-containing chelate-based ionic liquids. Physical chemistry chemical physics : PCCP 20:4109-17

84. Das A, Chatterjee S, Suresh Kumar G. 2017. Targeting human telomeric Gquadruplex DNA with antitumour natural alkaloid aristololactam-beta-Dglucoside and its comparison with daunomycin. Journal of molecular recognition : JMR 30

85. Heidari R, Mandegani L, Ghanbarinejad V, Siavashpour A, Ommati MM, et al. 2018. Mitochondrial dysfunction as a mechanism involved in the pathogenesis of cirrhosis-associated cholemic nephropathy. Biomedicine \& pharmacotherapy $=$ Biomedecine \& pharmacotherapie 109:271-80

86. Zhang M, Liu H, Wang Y, Ma T. 2018. A novel synthesis of Fe7S8@Fe5Ni4S8 flower center/petal hierarchical nanostructure: Application as advance cathode material for high-performance supercapacitors. Journal of colloid and interface science 536:609-17

87. Yi Y, Gao SR, Xia J, Li CY, Zhao Y, et al. 2018. Study of the accumulation and distribution of arsenic species and association with arsenic toxicity in rats after 30 days of oral realgar administration. Journal of ethnopharmacology

88. Schuurmans Stekhoven FM, van Heeswijk MP, de Pont JJ, Bonting SL. 1976. Studies on $(\mathrm{Na}++\mathrm{K}+)$-activated ATPase. XXXVIII. A 100000 molecular weight protein as the low-energy phosphorylated intermediate of the enzyme. Biochimica et biophysica acta 422:210-24

89. Hutchinson JP, Evenhuis CJ, Johns C, Kazarian AA, Breadmore MC, et al. 2007. Identification of inorganic improvised explosive devices by analysis of postblast residues using portable capillary electrophoresis instrumentation and indirect photometric detection with a light-emitting diode. Analytical chemistry 79:700513

90. Xie R, Jackson KA, Seip HM, McLeod CW, Wibetoe G, et al. 2009. Characteristics of water-soluble inorganic chemical components in size-resolved airborne particulate matters--Sheffield, UK. Journal of environmental monitoring : JEM 11:336-43

91. Liu J, Guo T, Luo Y, Chai X, Wu J, et al. 2018. Enhancement of Monascus pigment productivity via a simultaneous fermentation process and separation system using immobilized-cell fermentation. Bioresource technology 272:552-60

92. Thi Nguyen HY, Tran GB. 2018. Optimization of Fermentation Conditions and Media for Production of Glucose Isomerase from Bacillus megaterium Using Response Surface Methodology. Scientifica 2018:6842843

93. Olorunnisola KS, Jamal P, Alam MZ. 2018. Protein improvement of banana peel through sequential solid state fermentation using mixed-culture of Phanerochaete chrysosporium and Candida utilis. 3 Biotech 8:416

94. Cho ES, Cha IT, Roh SW, Nam YD, Seo MJ. 2018. Haloplanus rallus sp. nov., a halophilic archaeon isolated from crude solar salt. International journal of systematic and evolutionary microbiology 68:3226-31 
95. Ozgoren T, Pinar O, Bozdag G, Denizci AA, Gunduz O, et al. 2018. Assessment of poly(3-hydroxybutyrate) synthesis from a novel obligate alkaliphilic Bacillus marmarensis and generation of its composite scaffold via electrospinning. International journal of biological macromolecules 119:982-91

96. Reade S, Williams JM, Aggio R, Duckworth CA, Mahalhal A, et al. 2018. Potential role of fecal volatile organic compounds as biomarkers of chemically induced intestinal inflammation in mice. FASEB journal : official publication of the Federation of American Societies for Experimental Biology:fj201800076RR

97. Saboory E, Ghadimkhani M, Roshan-Milani S, Derafshpour L, Mohammadi S, et al. 2018. Effect of early-life inflammation and magnesium sulfate on hyperthermiainduced seizures in infant rats: Susceptibility to pentylenetetrazol-induced seizures later in life. Developmental psychobiology

98. Fazlali M, Kharazmi F, Kamran M, MaleKzadeh K, Talebi A, et al. 2018. Effect of oral magnesium sulfate administration on LOX-1 gene expression to prevent atherosclerosis in diabetic rat vessels. Journal of diabetes investigation

99. Ravilious GE, Herrmann J, Goo Lee S, Westfall CS, Jez JM. 2013. Kinetic mechanism of the dimeric ATP sulfurylase from plants. Bioscience reports 33

100. Xu Y, Wang L, Zhao L, Cui Y. 2011. Synthesis of polyaspartic acidaminobenzenesulfonic acid grafted copolymer and its scale inhibition performance and dispersion capacity. Water science and technology : a journal of the International Association on Water Pollution Research 64:423-30

101. Pinto RM, Costas MJ, Fernandez A, Canales J, Garcia-Agundez JA, Cameselle JC. 1991. Dinucleoside tetraphosphatase from human blood cells. Purification and characterization as a high specific activity enzyme recognized by an anti-rat tetraphosphatase antibody. FEBS letters 287:85-8

102. Hurtado C, Ruiz A, Sillero A, Sillero MA. 1987. Specific magnesium-dependent diadenosine 5',5'"-P1,P3-triphosphate pyrophosphohydrolase in Escherichia coli. Journal of bacteriology 169:1718-23

103. Ogilvie A, Antl W. 1983. Diadenosine tetraphosphatase from human leukemia cells. Purification to homogeneity and partial characterization. The Journal of biological chemistry 258:4105-9

104. Eddy AC, Bidwell GL, 3rd, George EM. 2018. Pro-angiogenic therapeutics for preeclampsia. Biology of sex differences 9:36

105. Diguisto C, Goffinet F, Lorthe E, Kayem G, Roze JC, et al. 2017. Providing active antenatal care depends on the place of birth for extremely preterm births: the EPIPAGE 2 cohort study. Archives of disease in childhood. Fetal and neonatal edition 102:F476-F82

106. Xiao F, Xu W, Feng Y, Fu F, Zhang X, et al. 2017. Intrathecal magnesium sulfate does not reduce the ED50 of intrathecal hyperbaric bupivacaine for cesarean delivery in healthy parturients: a prospective, double blinded, randomized doseresponse trial using the sequential allocation method. $B M C$ anesthesiology 17:8

107. Kore BP, Pardhi SA, Dhoble NS, Dhoble SJ, Swart HC. 2017. Luminescence characterization of Dy and Eu doped $\mathrm{Na} 6 \mathrm{Mg}(\mathrm{SO} 4) 4$ phosphors. Luminescence : the journal of biological and chemical luminescence 32:564-72

108. Bednarchuk TJ, Kinzhybalo V, Pietraszko A. 2016. Synthesis, structure and characterization of five new organically templated metal sulfates with 2aminopyridinium. Acta crystallographica. Section C, Structural chemistry 72:43241

109. Schuchmann K, Vonck J, Muller V. 2016. A bacterial hydrogen-dependent CO2 reductase forms filamentous structures. The FEBS journal 283:1311-22 
110. Rindelaub JD, Craig RL, Nandy L, Bondy AL, Dutcher CS, et al. 2016. Direct Measurement of $\mathrm{pH}$ in Individual Particles via Raman Microspectroscopy and Variation in Acidity with Relative Humidity. The journal of physical chemistry. A 120:911-7

111. Pan TM, Pan FH. 1992. Microbial production of citric acid from salad oil. Zhonghua Minguo wei sheng wu ji mian yi xue za zhi = Chinese journal of microbiology and immunology 25:129-37

112. Nugent KM, Cole RM. 1977. Characterization of group H streptococcal temperate bacteriophage phi 227. Journal of virology 21:1061-73

113. Darmenton P, Cronenberger L, Pacheco H. 1976. [Purification and properties of rat kidney catechol-O-methyltransferase]. Biochimie 58:1031-45

114. Dogterom P, Fu C, Legg T, Chiou YJ, Brandon S. 2018. The absolute bioavailability and the effect of food on a new magnesium lactate dihydrate extended-release caplet in healthy subjects. Drug development and industrial pharmacy 44:1481-7

115. Sciscione F, Manoli F, Viola E, Wankar J, Ercolani C, et al. 2017. Photoactivity of New Octacationic Magnesium(II) and Zinc(II) Porphyrazines in a Water Solution and G-Quadruplex Binding Ability of Differently Sized Zinc(II) Porphyrazines. Inorganic chemistry 56:12795-808

116. Kim DS, Yang ES, Yong CS, Youn YS, Oh KT, et al. 2017. Effect of inorganic mesoporous carriers on 1-palmitoyl-2-linoleoyl-3-acetyl-rac-glycerol-loaded solid self-emulsifying drug delivery system: Physicochemical characterization and bioavailability in rats. Colloids and surfaces. B, Biointerfaces 160:331-6

117. Zhang J, Brutus TE, Cheng J, Meng X. 2017. Fluoride removal by Al, Ti, and Fe hydroxides and coexisting ion effect. Journal of environmental sciences 57:190-5

118. Sanna A, Steel L, Maroto-Valer MM. 2017. Carbon dioxide sequestration using $\mathrm{NaHSO} 4$ and $\mathrm{NaOH}$ : A dissolution and carbonation optimisation study. Journal of environmental management 189:84-97

119. Kaewthong P, Wattanachant S. 2018. Optimizing the electrical conductivity of marinade solution for water-holding capacity of broiler breast meat. Poultry science $97: 701-8$

120. Hietzschold S, Hillebrandt S, Ullrich F, Bombsch J, Rohnacher V, et al. 2017. Functionalized Nickel Oxide Hole Contact Layers: Work Function versus Conductivity. ACS applied materials \& interfaces 9:39821-9

121. Alizadeh A, Wang M. 2017. Direct simulation of electroosmosis around a spherical particle with inhomogeneously acquired surface charge. Electrophoresis 38:58095

122. Fan Z, Du D, Yu Z, Li P, Xia Y, Ouyang J. 2016. Significant Enhancement in the Thermoelectric Properties of PEDOT:PSS Films through a Treatment with Organic Solutions of Inorganic Salts. ACS applied materials \& interfaces 8:23204-11

123. Kumar B, Bhardwaj N, Alam A, Agrawal K, Prasad H, Verma P. 2018. Production, purification and characterization of an acid/alkali and thermo tolerant cellulase from Schizophyllum commune NAIMCC-F-03379 and its application in hydrolysis of lignocellulosic wastes. $A M B$ Express 8:173

124. Musa H, Hafiz Kasim F, Nagoor Gunny AA, Gopinath SCB, Azmier Ahmad M. 2018. Enhanced halophilic lipase secretion by Marinobacter litoralis SW-45 and its potential fatty acid esters release. Journal of basic microbiology

125. Tolera M, Teklu AM, Ahmed A, Hashi A, Oljira L, et al. 2018. Use of a qualitative case study to learn lessons from severe preeclampsia causing a maternal nearmiss: a case report. Journal of medical case reports 12:277 
126. Walia C, Gupta R, Kaur M, Mahajan L, Kaur G, Kaur B. 2018. Propofol sparing effect of dexmedetomidine and magnesium sulfate during BIS targeted anesthesia: A prospective, randomized, placebo controlled trial. Journal of anaesthesiology, clinical pharmacology 34:335-40

127. Karimi A, Radfard M, Abbasi M, Naghizadeh A, Biglari H, et al. 2018. Fluoride concentration data in groundwater resources of Gonabad, Iran. Data in brief 21:105-10

128. Schumacher SA, Yardley J, Bertone AL. 2018. Ionized magnesium and calcium concentration and their ratio in equine plasma samples as determined by a regulatory laboratory compared to a clinical reference laboratory. Drug testing and analysis

129. Harsono AAH, Achmadi A, Aldika Akbar MI, Joewono HT. 2018. Recurrent Seizures in 2 Patients with Magnesium Sulfate-Treated Eclampsia at a Secondary Hospital. The American journal of case reports 19:1129-34

130. Kumar D, Kumar A, Sondhi S, Sharma P, Gupta N. 2018. An alkaline bacterial laccase for polymerization of natural precursors for hair dye synthesis. 3 Biotech 8:182

131. Sawatdee S, Atipairin A, Sae Yoon A, Srichana T, Changsan N. 2017. Enhanced dissolution of sildenafil citrate as dry foam tablets. Pharmaceutical development and technology:1-11

132. Abd El-Hack ME, Samak DH, Noreldin AE, Arif M, Yaqoob HS, Swelum AA. 2018. Towards saving freshwater: halophytes as unconventional feedstuffs in livestock feed: a review. Environmental science and pollution research international 25:14397-406

133. Bello FH, Maiha BB, Anuka JA. 2016. The effect of methanol rhizome extract of Nymphaea lotus Linn. (Nymphaeaceae) in animal models of diarrhoea. Journal of ethnopharmacology 190:13-21

134. Erickson Al, Sarsam RD, Fisher AJ. 2015. Crystal Structures of Mycobacterium tuberculosis CysQ, with Substrate and Products Bound. Biochemistry 54:6830-41

135. Feng P, Garboczi EJ, Miao C, Bullard JW. 2015. Microstructural Origins of Cement Paste Degradation by External Sulfate Attack. Construction and building materials 96:391-403

136. Hsiao HY, Chen BH, Kao TH. 2017. Analysis of Heterocyclic Amines in Meat by the Quick, Easy, Cheap, Effective, Rugged, and Safe Method Coupled with LC-DADMS-MS. Journal of agricultural and food chemistry 65:9360-8

137. Khalilzadeh M, Abdollahi A, Abdolahi F, Abdolghaffari AH, Dehpour AR, Jazaeri F. 2018. Protective effects of magnesium sulfate against doxorubicin induced cardiotoxicity in rats. Life sciences 207:436-41

138. Pal PK, Mahajan M. 2017. Pruning System and Foliar Application of MgSO 4 Alter Yield and Secondary Metabolite Profile of Rosa damascena under Rainfed Acidic Conditions. Frontiers in plant science 8:507

139. Panahi Y, Mojtahedzadeh M, Najafi A, Ghaini MR, Abdollahi M, et al. 2017. The role of magnesium sulfate in the intensive care unit. EXCLI journal 16:464-82

140. Beuscher N, Mayer F, Gottschalk G. 1974. Citrate lyase from Rhodopseudomonas gelatinosa: purification, electron microscopy and subunit structure. Archives of microbiology 100:307-28

141. 2006. Magnesium Sulfate. In Drugs and Lactation Database (LactMed). Bethesda (MD). Number of. 
142. Cole NI, Suckling RJ, Swift PA, He FJ, MacGregor GA, et al. 2018. The association between serum sodium concentration, hypertension and primary cardiovascular events: a retrospective cohort study. Journal of human hypertension

143. Bokhari SR, Siriki R, Teran FJ, Batuman V. 2018. Fatal Hypermagnesemia Due to Laxative Use. The American journal of the medical sciences 355:390-5

144. Adams JB, Audhya T, Geis E, Gehn E, Fimbres V, et al. 2018. Comprehensive Nutritional and Dietary Intervention for Autism Spectrum Disorder-A Randomized, Controlled 12-Month Trial. Nutrients 10

145. Feinstein JS, Khalsa SS, Yeh HW, Wohlrab C, Simmons WK, et al. 2018. Examining the short-term anxiolytic and antidepressant effect of Floatation-REST. PloS one 13:e0190292

146. Philips CA, Paramaguru R, Mahadevan P, Augustine P. 2017. Severe liver injury due to Epsom salt naturopathy. BMJ case reports 2017

147. Barnhart ER, Ash RJ. 1975. Physical characteristic of herpesvirions: lowtemperature and osmotic-shock studies. Virology 66:563-7

148. Grobman WA, Lai Y, Rouse DJ, Spong CY, Varner MW, et al. 2013. The association of cerebral palsy and death with small-for-gestational-age birthweight in preterm neonates by individualized and population-based percentiles. American journal of obstetrics and gynecology 209:340 e1-5

149. Mondal NC, Singh VP, Singh S, Singh VS. 2011. Hydrochemical characteristic of coastal aquifer from Tuticorin, Tamil Nadu, India. Environmental monitoring and assessment 175:531-50

150. Shin DH, Roberts A, Jancarik J, Yokota H, Kim R, et al. 2003. Crystal structure of a phosphatase with a unique substrate binding domain from Thermotoga maritima. Protein science : a publication of the Protein Society 12:1464-72

151. Takano Y, Sato E, Kaneko T, Sato I. 2000. Antihyperalgesic effects of intrathecally administered magnesium sulfate in rats. Pain 84:175-9

152. Wang Y, Fang X, An F, Wang G, Zhang X. 2011. Improvement of antibiotic activity of Xenorhabdus bovienii by medium optimization using response surface methodology. Microbial cell factories 10:98

153. Yang LL, Zhang DQ. 2002. Direct determination of germanium in botanical samples by graphite furnace atomic absorption spectrometry with palladiumzirconium as chemical modifier. Talanta 56:1123-9

154. Yun JS, Ha SC, Kim S, Kim YG, Kim H, Chang JH. 2018. Crystal structure of Arabidopsis thaliana RabA1a. Journal of integrative plant biology

155. Schwendner P, Bohmeier M, Rettberg P, Beblo-Vranesevic K, Gaboyer F, et al. 2018. Beyond Chloride Brines: Variable Metabolomic Responses in the Anaerobic Organism Yersinia intermedia MASE-LG-1 to $\mathrm{NaCl}$ and $\mathrm{MgSO} 4$ at Identical Water Activity. Frontiers in microbiology 9:335

156. Azim MK, Mehnaz A, Ahmed JZ, Mujtaba G. 2018. Exome sequencing identifies a novel frameshift variant causing hypomagnesemia with secondary hypocalcemia. CEN case reports

157. Scibior A, Adamczyk A, Golebiowska D, Kurus J. 2018. Evaluation of lipid peroxidation and the level of some elements in rat erythrocytes during separate and combined vanadium and magnesium administration. Chemico-biological interactions 293:1-10

158. Bedi A, Singh BR, Deshmukh SK, Aggarwal N, Barrow CJ, Adholeya A. 2018. Development of a novel myconanomining approach for the recovery of agriculturally important elements from jarosite waste. Journal of environmental sciences 67:356-67 
159. Guo Q, Zhao S, Zhang J, Qi K, Du Z, Shao B. 2018. Determination of fipronil and its metabolites in chicken egg, muscle and cake by a modified QuEChERS method coupled with LC-MS/MS. Food additives \& contaminants. Part A, Chemistry, analysis, control, exposure \& risk assessment 35:1543-52

160. Vithana MDK, Singh Z, Johnson SK. 2018. Levels of terpenoids, mangiferin and phenolic acids in the pulp and peel of ripe mango fruit influenced by pre-harvest spray application of FeSO4 $(\mathrm{Fe}(2+)), \mathrm{MgSO} 4(\mathrm{Mg}(2+))$ and $\mathrm{MnSO} 4(\mathrm{Mn}(2+))$. Food chemistry 256:71-6

161. Celik Kavak E, Gulcu Bulmus F, Bulmus O, Kavak SB, Kocaman N. 2018. Magnesium: does it reduce ischemia/reperfusion injury in an adnexal torsion rat model? Drug design, development and therapy 12:409-15

162. Chen SC, Lin WH, Chien CC, Tsang DCW, Kao CM. 2018. Development of a twostage biotransformation system for mercury-contaminated soil remediation. Chemosphere 200:266-73

163. Almessiere MA, Altuwiriqi R, Gondal MA, AlDakheel RK, Alotaibi HF. 2018. Qualitative and quantitative analysis of human nails to find correlation between nutrients and vitamin D deficiency using LIBS and ICP-AES. Talanta 185:61-70

164. Kose O, Turan A, Unal M, Acar B, Guler F. 2018. Fixation of medial malleolar fractures with magnesium bioabsorbable headless compression screws: shortterm clinical and radiological outcomes in eleven patients. Archives of orthopaedic and trauma surgery 138:1069-75

165. Lvova L, Goncalves CG, Di Natale C, Legin A, Kirsanov D, Paolesse R. 2018. Recent advances in magnesium assessment: From single selective sensors to multisensory approach. Talanta 179:430-41

166. Plaass C, von Falck C, Ettinger S, Sonnow L, Calderone F, et al. 2018. Bioabsorbable magnesium versus standard titanium compression screws for fixation of distal metatarsal osteotomies - 3 year results of a randomized clinical trial. Journal of orthopaedic science : official journal of the Japanese Orthopaedic Association 23:321-7

167. Tice MM, Quezergue K, Pope MC. 2017. Microbialite Biosignature Analysis by Mesoscale X-ray Fluorescence (muXRF) Mapping. Astrobiology 17:1161-72

168. Cheng Y, Huang T, Cheng L, Sun Y, Zhu L, Li Y. 2018. Structural characteristic and ammonium and manganese catalytic activity of two types of filter media in groundwater treatment. Journal of environmental sciences 72:89-97

169. Yuan X, Xiong T, Wang H, Wu Z, Jiang L, et al. 2018. Immobilization of heavy metals in two contaminated soils using a modified magnesium silicate stabilizer. Environmental science and pollution research international 25:32562-71

170. Birca AC, Neacsu IA, Vasile OR, Ciuca I, Vasile IM, et al. 2018. Mg-Zn alloys, most suitable for biomedical applications. Romanian journal of morphology and embryology = Revue roumaine de morphologie et embryologie 59:49-54

171. Wang Y, Liu Z, Wang C, Yi X, Chen R, et al. 2018. Highly Branched VS4 Nanodendrites with 1D Atomic-Chain Structure as a Promising Cathode Material for Long-Cycling Magnesium Batteries. Advanced materials 30:e1802563

172. Zhou Y, Liu X, Huang N, Chen Y. 2018. Magnesium ion leachables induce a conversion of contractile vascular smooth muscle cells to an inflammatory phenotype. Journal of biomedical materials research. Part $B$, Applied biomaterials

173. Xu H, Zhang Z, Li J, Qiao L, Lu C, et al. 2018. Multifunctional Additives Improve the Electrolyte Properties of Magnesium Borohydride Toward Magnesium-Sulfur Batteries. ACS applied materials \& interfaces 10:23757-65 
174. Karki I, Christen MT, Spiriti J, Slack RL, Oda M, et al. 2016. Entire-Dataset Analysis of NMR Fast-Exchange Titration Spectra: A Mg(2+) Titration Analysis for HIV-1 Ribonuclease H Domain. The journal of physical chemistry. B 120:12420-31

175. Kim HT, Lee TG. 2017. A simultaneous stabilization and solidification of the top five most toxic heavy metals ( $\mathrm{Hg}, \mathrm{Pb}, \mathrm{As}, \mathrm{Cr}$, and $\mathrm{Cd})$. Chemosphere 178:479-85

176. Kitagawa T, Funaba M, Matsui T. 2018. Relationships between mineral concentrations and physicochemical characteristics in the Longissimus thoracis muscle of Japanese Black cattle. Animal science journal = Nihon chikusan Gakkaiho 89:211-8

177. Kumari GK, Krishna Ch R, Begum SM, Manjari VP, Murthy PN, Ravikumar RV. 2013. Mixed alkali effect in $\mathrm{Mn} 2+$ doped $20 \mathrm{ZnO}+\mathrm{xLi2O}+(30-\mathrm{x}) \mathrm{K} 2 \mathrm{O}+50 \mathrm{~B} 2 \mathrm{O} 3(5</=\mathrm{x}</=25)$ glasses. Spectrochimica acta. Part A, Molecular and biomolecular spectroscopy 101:140-7

178. Lee JJ, Moon Y, Han JH, Jeong S. 2017. Analysis of major elements in pigmented melanocytic chicken skin using laser-induced breakdown spectroscopy. Journal of biophotonics 10:523-31

179. Shah RR. 2017. Anti-Angiogenic Tyrosine Kinase Inhibitors and Reversible Posterior Leukoencephalopathy Syndrome: Could Hypomagnesaemia Be the Trigger? Drug safety 40:373-86

180. Dey A, Confer AM, Vilbert AC, Moenne-Loccoz P, Lancaster KM, Goldberg DP. 2018. A Nonheme Sulfur-Ligated $\{\mathrm{FeNO}\}(6)$ Complex and Comparison with RedoxInterconvertible $\{\mathrm{FeNO}\}(7)$ and $\{\mathrm{FeNO}\}(8)$ Analogues. Angewandte Chemie $57: 13465-9$

181. Dong R, Zhao M, Xia W, Yi X, Dai P, Tang N. 2018. Chemical and microscopic investigation of co-pyrolysis of crumb tire rubber with waste cooking oil at mild temperature. Waste management 79:516-25

182. Zhong H, llyas N, Song Y, Li W, Jiang Y. 2018. Enhanced near-infrared absorber: two-step fabricated structured black silicon and its device application. Nanoscale research letters 13:316

183. Lin $\mathrm{X}$, Hetharua $\mathrm{B}$, Lin L, Xu H, Zheng T, et al. 2018. Mangrove Sediment Microbiome: Adaptive Microbial Assemblages and Their Routed Biogeochemical Processes in Yunxiao Mangrove National Nature Reserve, China. Microbial ecology

184. Grell TAJ, Kincannon WM, Bruender NA, Blaesi EJ, Krebs C, et al. 2018. Structural and spectroscopic analyses of the sporulation killing factor biosynthetic enzyme $\mathrm{SkfB}$, a bacterial AdoMet radical sactisynthase. The Journal of biological chemistry

185. Shi Y, Li P, Yu X, Wang H, Niu L. 2018. Evaluating Doctor Performance: Ordinal Regression-Based Approach. Journal of medical Internet research 20:e240

186. Amino $\mathrm{Y}$, Wakabayashi $\mathrm{H}$, Akashi S, Ishiwatari Y. 2018. Structural analysis and taste evaluation of gamma-glutamyl peptides comprising sulfur-containing amino acids. Bioscience, biotechnology, and biochemistry 82:383-94

187. Borsodi AK, Sziranyi B, Krett G, Marialigeti K, Janurik E, Pekar F. 2016. Changes in the water quality and bacterial community composition of an alkaline and saline oxbow lake used for temporary reservoir of geothermal waters. Environmental science and pollution research international 23:17676-88

188. Gilbert-Lopez B, Dernovics M, Moreno-Gonzalez D, Molina-Diaz A, Garcia-Reyes JF. 2017. Detection of over 100 selenium metabolites in selenized yeast by liquid chromatography electrospray time-of-flight mass spectrometry. Journal of chromatography. B, Analytical technologies in the biomedical and life sciences 1060:84-90 
189. Miseta R, Palatinszky M, Makk J, Marialigeti K, Borsodi AK. 2013. Spatial and temporal changes of bacterial communities inhabiting the well waters of Harkany Spa. Acta microbiologica et immunologica Hungarica 60:329-43

190. Oliveira NC, Silva JH, Barros OA, Pinheiro AP, Santana W, et al. 2015. Large-field electron imaging and $\mathrm{X}$-ray elemental mapping unveil the morphology, structure, and fractal features of a Cretaceous fossil at the centimeter scale. Analytical chemistry 87:10088-95

191. Jaworski K, Maslanka K, Jakimiuk A, Lopacz P, Panin P, Kosior DA. 2016. Transfusion-related acute lung injury in a young woman with ectopic pregnancy case report and literature review. Ginekologia polska 87:231-4

192. Primosch R, McLellan M, Jerrell G, Venezie R. 1997. Effect of scavenging on the psychomotor and cognitive function of subjects sedated with nitrous oxide and oxygen inhalation. Pediatric dentistry 19:480-3

193. Trost BM, Brown BS, McEachern EJ, Kuhn O. 2003. Asymmetric synthesis of oxygen heterocycles via Pd-catalyzed dynamic kinetic asymmetric transformations: application to nucleosides. Chemistry 9:4442-51

194. Pelster B, Wood CM, Jung E, Val AL. 2018. Air-breathing behavior, oxygen concentrations, and ROS defense in the swimbladders of two erythrinid fish, the facultative air-breathing jeju, and the non-air-breathing traira during normoxia, hypoxia and hyperoxia. Journal of comparative physiology. B, Biochemical, systemic, and environmental physiology 188:437-49

195. Rasmusson LM, Lauritano C, Procaccini G, Gullstrom M, Buapet P, Bjork M. 2017. Respiratory oxygen consumption in the seagrass Zostera marina varies on a diel basis and is partly affected by light. Marine biology 164:140

196. Shetty S, Hunt K, Peacock J, Ali K, Greenough A. 2017. Crossover study of assist control ventilation and neurally adjusted ventilatory assist. European journal of pediatrics 176:509-13

197. Zuo Z, Wang D, Zhang J, Lu F, Li Y. 2018. Synthesis and Applications of GraphdiyneBased Metal-Free Catalysts. Advanced materials:e1803762

198. Kashef N, Huang YY, Hamblin MR. 2017. Advances in antimicrobial photodynamic inactivation at the nanoscale. Nanophotonics 6:853-79

199. Khosravi Y, Salimi A, Pourahmad J, Naserzadeh P, Seydi E. 2018. Inhalation exposure of nano diamond induced oxidative stress in lung, heart and brain. Xenobiotica; the fate of foreign compounds in biological systems 48:860-6

200. Borowska-Solonynko A, Dabkowska A. 2018. Gas embolism as a potential cause of death by helium poisoning - Postmortem computed tomography changes in two cases of suicidal helium inhalation. Legal medicine 31:59-65

201. Geng H, Qiu J, Zhu H, Liu X. 2018. Achieving stem cell imaging and osteogenic differentiation by using nitrogen doped graphene quantum dots. Journal of materials science. Materials in medicine 29:85

202. Yang SY, Zhao J, Yu HZ, Peng L, Xiao L. 2017. [Vertical Distribution Characteristics of $\mathrm{Fe}$ and $\mathrm{Mn}$ in Subtropical Reservoirs During Summer]. Huan jing ke xue= Huanjing kexue 38:4546-52

203. Yu C, Liu DW, Wang XT, He HW, Pan P, Xing ZQ. 2018. [The clinical significance of microcirculation and oxygen metabolism evaluation in acute kidney injury assessment in patients with septic shock after resuscitation]. Zhonghua nei ke za zhi 57:123-8

204. Patra P, Ghosh M, Banerjee R, Chakrabarti J. 2018. Quantum chemical studies on anion specificity of C(alpha)NN motif in functional proteins. Journal of computeraided molecular design 32:929-36 
205. Shaharom S, Latif MT, Khan MF, Yusof SNM, Sulong NA, et al. 2018. Surfactants in the sea surface microlayer, subsurface water and fine marine aerosols in different background coastal areas. Environmental science and pollution research international 25:27074-89

206. Nieva NE, Borgnino L, Garcia MG. 2018. Long term metal release and acid generation in abandoned mine wastes containing metal-sulphides. Environmental pollution 242:264-76

207. Koshani R, van de Ven TGM, Madadlou A. 2018. Characterization of Carboxylated Cellulose Nanocrytals Isolated through Catalyst-Assisted H2O2 Oxidation in a One-Step Procedure. Journal of agricultural and food chemistry 66:7692-700

208. Gan YY, Zhou SL, Dai X, Wu H, Xiong ZY, et al. 2018. Effect of iron salt type and dosing mode on Fenton-based pretreatment of rice straw for enzymatic hydrolysis. Bioresource technology 265:394-8

209. Hara T, Tatsuishi H, Banno T, Fujie T, Yamamoto C, et al. 2018. Copper(II) Bis(diethyldithiocarbamate) Induces the Expression of Syndecan-4, a Transmembrane Heparan Sulfate Proteoglycan, via p38 MAPK Activation in Vascular Endothelial Cells. International journal of molecular sciences 19

210. Boronat A, Martinez-Huelamo M, Cobos A, de la Torre R. 2018. Wine and Olive Oil Phenolic Compounds Interaction in Humans. Diseases 6

211. Wang X, Chen H, Li R, Fu W, Yao C. 2018. The effects of respiratory inhaled drugs on the prevention of acute mountain sickness. Medicine 97:e11788

212. Jones ML, Pizarro KA. 1994. A comparative study of the shear bond strengths of four different crystal growth solutions. British journal of orthodontics 21:133-7

213. Osheroff N. 1986. Eukaryotic topoisomerase II. Characterization of enzyme turnover. The Journal of biological chemistry 261:9944-50

214. Zainul R, Oktavia B, Dewata I, Efendi J. Thermal and Surface Evaluation on The Process of Forming a Cu2O/CuO Semiconductor Photocatalyst on a Thin Copper Plate. Proc. IOP Conference Series: Materials Science and Engineering, 2018, 335:012039: IOP Publishing

215. Febriani SS, Yolanda T, Arianti VA, Zainul R. 2018. A Review Solid Stated: Principles and Methode.

216. Zainul R, Alif A, Aziz H, Arief S, Dradjad S, Munaf E. 2015. Design of photovoltaic cell with copper oxide electrode by using indoor lights. RESEARCH JOURNAL OF PHARMACEUTICAL BIOLOGICAL AND CHEMICAL SCIENCES 6:353-61

217. Liza YM, Yasin RC, Maidani SS, Zainul R. 2018. SOL GEL: PRINCIPLE AND TECHNIQUE (A REVIEW).

218. Dinata AA, Rosyadi AM, Hamid S, Zainul R. 2018. A Review CHEMICAL VAPOR DEPOSITION: PROCESS AND APPLICATION.

219. Stachowska-Pietka J, Poleszczuk J, Flessner MF, Lindholm B, Waniewski J. 2018. Alterations of peritoneal transport characteristics in dialysis patients with ultrafiltration failure: tissue and capillary components. Nephrology, dialysis, transplantation : official publication of the European Dialysis and Transplant Association - European Renal Association

220. He Y, Bai P, Gao S, Xu Y. 2018. The Marriage of An Ether-Based Electrolyte with Hard Carbon Anodes Creates Superior Sodium-Ion Batteries with High Mass Loading. ACS applied materials \& interfaces

221. Bahuguna BP, Saini LK, Sharma RO, Tiwari B. 2018. Hybrid functional calculations of electronic and thermoelectric properties of GaS, GaSe, and GaTe monolayers. Physical chemistry chemical physics : PCCP 
222. Li X, Gao P, Tan J, Xiong K, Maitz MF, et al. 2018. Assembly of MetalPhenolic/Catecholamine Networks for Synergistically Anti-Inflammatory, Antimicrobial and Anticoagulant Coatings. ACS applied materials \& interfaces

223. Hartouni EP, Beeman B, Eckart MJ, Grim GP, Hatarik R, et al. 2018. Uncertainty analysis of response functions and gamma -backgrounds on Tion and t0 measurements from Cherenkov neutron detectors at the National Ignition Facility (NIF). The Review of scientific instruments 89:101140

224. Lockard TE, Magee EW, Layne DA, Leutenegger MA, Eckart ME, et al. 2018. The Warm Electron Beam Ion Trap (WEBIT): An instrument for ground calibration of space-borne x-ray spectrometers. The Review of scientific instruments 89:10F124

225. Dunne AE, Kawamatawong T, Fenwick PS, Davies CM, Tullett $H$, et al. 2018. Direct Inhibitory Effect of the Phosphodiesterase-4 Inhibitor, Roflumilast, on Neutrophil Migration in COPD. American journal of respiratory cell and molecular biology

226. Awalliyah A, Ikhwan H, Nugiasari V, Zainul R. 2018. A REVIEW PRINSIP DASAR MILLING DALAM SINTESIS MATERIAL.

227. Shtepliuk I, Santangelo MF, Vagin M, Ivanov IG, Khranovskyy V, et al. 2018. Understanding Graphene Response to Neutral and Charged Lead Species: Theory and Experiment. Materials 11

228. Kingsbury RS, Zhu S, Flotron S, Coronell O. 2018. Microstructure determines water and salt permeation in commercial ion exchange membranes. ACS applied materials \& interfaces

229. Aziz SB, Faraj MG, Abdullah OG. 2018. Impedance Spectroscopy as a Novel Approach to Probe the Phase Transition and Microstructures Existing in CS:PEO Based Blend Electrolytes. Scientific reports 8:14308

230. Li YJ, Fan CY, Zhang JP, Wu XL. 2018. A promising PMHS/PEO blend polymer electrolyte for all-solid-state lithium ion batteries. Dalton transactions 47:149327

231. Seman R, Azam MA, Ani MH. 2018. Graphene/transition metal dichalcogenides hybrid supercapacitor electrode: status, challenges, and perspectives. Nanotechnology 29:502001

232. Candani D, Ulfah M, Noviana W, Zainul R. 2018. A Review Pemanfaatan Teknologi Sonikasi.

233. Yang Z, Zarabi S, Fernandes E, Rua-Taborda MI, Debeda H, et al. 2018. A Simple Wireless Sensor Node System for Electricity Monitoring Applications: Design, Integration, and Testing with Different Piezoelectric Energy Harvesters. Sensors 18

234. Hess H, Saper G. 2018. Engineering with Biomolecular Motors. Accounts of chemical research

235. Kravchyk KV, Bhauriyal P, Piveteau L, Guntlin CP, Pathak B, Kovalenko MV. 2018. High-energy-density dual-ion battery for stationary storage of electricity using concentrated potassium fluorosulfonylimide. Nature communications 9:4469

236. Fatimah P, Jumalia R, Novianti ER, Zainul R. 2018. A REVIEW Teknik Blended: Prinsip dan Dasar-Dasar.

237. Gupta R, Rajeev KP, Hossain Z. 2018. Thermal transport studies on charge density wave materials LaPt2Si2 and PrPt2Si2. Journal of physics. Condensed matter : an Institute of Physics journal 30:475603

238. Matubayasi N. 2018. Spatial-Decomposition Analysis of Electrical Conductivity. Chemical record 
239. Lenis-Rojas OA, Robalo MP, Tomaz Al, Carvalho A, Fernandes AR, et al. 2018. $\mathrm{Ru}(\mathrm{II})(\mathrm{p}$-cymene) Compounds as Effective and Selective Anticancer Candidates with No Toxicity in Vivo. Inorganic chemistry 57:13150-66

240. Zheng J, Teng G, Yang J, Xu M, Yao Q, et al. 2018. Mechanism of Exact Transition between Cationic and Anionic Redox Activities in Cathode Material Li2FeSiO4. The journal of physical chemistry letters 9:6262-8

241. Fan S, Shen W, Liu J, Hei H, Hu R, et al. 2018. Solution-Based Property Tuning of Black Phosphorus. ACS applied materials \& interfaces

242. Zainul R. 2016. Design and Modification of Copper Oxide Electrodes for Improving Conversion Coefficient Indoors Lights (PV-Cell) Photocells.

243. Waitukaitis S, Harth K, van Hecke M. 2018. From Bouncing to Floating: The Leidenfrost Effect with Hydrogel Spheres. Physical review letters 121:048001

244. Ji B, Song Q, Yao Q. 2018. Limit for Small Spheres To Float by Dynamic Analysis. Langmuir : the ACS journal of surfaces and colloids 34:10163-8

245. Qin B, Yang G, Ma J, Wu T, Li W, et al. 2018. Spatiotemporal Changes of Cyanobacterial Bloom in Large Shallow Eutrophic Lake Taihu, China. Frontiers in microbiology 9:451

246. Andres M, Muglia M, Bahr F, Bane J. 2018. Continuous Flow of Upper Labrador Sea Water around Cape Hatteras. Scientific reports 8:4494

247. Beck TW, Seaman CE, Shahan MR, Mischler SE. 2018. Open-air sprays for capturing and controlling airborne float coal dust on longwall faces. Mining engineering 70:42-8

248. Markovic M, Ben-Shabat S, Keinan S, Aponick A, Zimmermann EM, Dahan A. 2018. Prospects and Challenges of Phospholipid-Based Prodrugs. Pharmaceutics 10

249. Pletinck A, Van Biesen W, Dequidt C, Eloot S. 2018. Transport of neutral IgG2 versus anionic IgG4 in PD: implications on the electrokinetic model. BMC nephrology 19:299

250. Dokko K, Watanabe D, Ugata Y, Thomas ML, Tsuzuki S, et al. 2018. Direct Evidence for Li Ion Hopping Conduction in Highly Concentrated Sulfolane-Based Liquid Electrolytes. The journal of physical chemistry. $B$

251. Chadda KR, Edling CE, Valli H, Ahmad S, Huang CL, Jeevaratnam K. 2018. Gene and Protein Expression Profile of Selected Molecular Targets Mediating Electrophysiological Function in Pgc-1alpha Deficient Murine Atria. International journal of molecular sciences 19

252. Miyazawa S, Hosono R, Osuga R, Kondo JN, Uchida S. 2018. Effect of the ammonium ion on proton conduction in porous ionic crystals based on Keggintype silicododecatungstate. Acta crystallographica. Section C, Structural chemistry 74:1289-94

253. Hu X, Wang W, Xie G, Wang H, Tan X, et al. 2018. Ternary assembly of gC3N4/graphene oxide sheets /BiFeO3 heterojunction with enhanced photoreduction of $\mathrm{Cr}(\mathrm{VI})$ under visible-light irradiation. Chemosphere 216:733-41

254. Hellevang $\mathrm{H}$, Huang $\mathrm{S}$, Thorseth IH. 2011. The potential for low-temperature abiotic hydrogen generation and a hydrogen-driven deep biosphere. Astrobiology 11:711-24

255. Melnick JL. 1996. Thermostability of poliovirus and measles vaccines. Developments in biological standardization 87:155-60

256. Dock AC, Lorber B, Moras D, Pixa G, Thierry JC, Giege R. 1984. Crystallization of transfer ribonucleic acids. Biochimie 66:179-201

257. Brawerman G. 1973. The isolation of RNA from mammalian cells. Methods in cell biology 7:1-22 
258. Vishnevskii AA, Portnoi VF, Cherkashchenko LN. 1973. [Preservation of the heart]. Vestnik Akademii meditsinskikh nauk SSSR 28:16-23

259. Proctor E. 1972. Preservation of the heart. Guy's Hospital reports 121:73-89

260. Childs JW, Lower RR. 1969. Preservation of the heart. Progress in cardiovascular diseases 12:149-63

261. Pathak L, Singh V, Niwas R, Osama K, Khan S, et al. 2015. Artificial Intelligence versus Statistical Modeling and Optimization of Cholesterol Oxidase Production by using Streptomyces Sp. PloS one 10:e0137268 